\title{
Quaternary evolution of glaciated gneiss terrains: pre-glacial weathering vs. glacial erosion
}

\author{
Maarten Krabbendam*, Tom Bradwell \\ British Geological Survey, Murchison House, Edinburgh EH6 3LA,United Kingdom \\ (* Corresponding author. Tel ++44 131 6500256. Email address: mkrab@bgs.ac.uk)
}

\begin{abstract}
Vast areas previously covered by Pleistocene ice sheets consist of rugged bedrock-dominated terrain of innumerable knolls and lake-filled rock basins - the ‘cnoc-and-lochan' landscape or 'landscape of areal scour'. These landscapes typically form on gneissose or granitic lithologies and are interpreted (1) either to be the result of strong and widespread glacial erosion over numerous glacial cycles; or (2) formed by stripping of a saprolitic weathering mantle from an older, deeply weathered landscape.

We analyse bedrock structure, erosional landforms and weathering remnants and within the 'cnoc-andlochan' gneiss terrain of a rough peneplain in NW Scotland and compare this with a geomorphologically similar gneiss terrain in a non-glacial, arid setting (Namaqualand, South Africa). We find that the topography of the gneiss landscapes in NW Scotland and Namaqualand closely follows the old bedrock—saprolite contact (weathering front). The roughness of the weathering front is caused by deep fracture zones providing a highly irregular surface area for weathering to proceed. The weathering front represents a significant change in bedrock physical properties. Glacial erosion (and aeolian erosion in Namaqualand) is an efficient way of stripping saprolite, but is far less effective in eroding hard, unweathered bedrock. Significant glacial erosion of hard gneiss probably only occurs beneath palaeo-ice streams.

We conclude that the rough topography of glaciated 'cnoc-and-lochan' gneiss terrains is formed by a multistage process:

1) Long-term, pre-glacial chemical weathering, forming deep saprolite with an irregular weathering front;

2) Stripping of weak saprolite by glacial erosion during the first glaciation(s), resulting in a rough land surface, broadly conforming to the pre-existing weathering front ('etch surface');

3) Further modification of exposed hard bedrock by glacial erosion. In most areas, glacial erosion is limited, but can be significant beneath palaeo-ice stream. The roughness of glaciated gneiss terrains is crucial for modelling of the glacial dynamics of present-day ice sheets. This roughness is shown here to depend on the intensity of pre-glacial weathering as well as glacial erosion during successive glaciations.
\end{abstract}

Keywords: weathering; glacial erosion; shield terrain; subglacial roughness; fracture zone; saprolite; joint 


\section{Introduction}

In the Northern hemisphere, Pleistocene ice sheets covered large flat-lying shield areas, now typically characterised by an exposed bedrock landscape of numerous knolls or ridges and a multitude of lake-filled basins. Although the large-scale relief of this landscape is limited, such landscapes commonly show a rugged undulating hilly relief, narrow linear valleys and an abundance of closed rock basins. Roughness wavelength typically ranges from $10-1000 \mathrm{~m}$ and amplitudes up to $100 \mathrm{~m}$. Such landscapes cover much of eastern Canada, Finland, Sweden, West Greenland and NW Scotland (e.g. Rastas and Seppälä, 1981; Rea and Evans, 1996; Roberts and Long, 2005; Sugden, 1978). The landscape is commonly referred to as a 'landscape of areal scour' (Benn and Evans, 2011; Rea and Evans, 1996; Sugden and John, 1976). In Scotland, the more descriptive term 'cnoc-and-lochan' terrain, often written as the Anglizised version 'knock-and-lochan', (from Gaelic; cnoc = knoll; lochan = small lake) is commonly used (Linton, 1963). Although these landscapes differ regionally in relative relief, they are significantly rougher than till-covered plains as found for instance in Saskatchewan and in northern Germany or Poland.

Cnoc-and-lochan terrains are typically underlain by crystalline basement 'shield' rocks such as gneisses and granitic rocks, and it is clear that the characteristics of these rocks are important in the development of these landscapes.

The geomorphology and landscape evolution of deglaciated gneiss terrains is important for a number of reasons:

1) Basement gneiss, together with similar granitic rocks, cover significant areas previously occupied by Pleistocene Northern Hemisphere ice sheets, and thus form much of the former bed of these globally important former ice masses. Around $80 \%$ of the onshore Fennoscandian Ice Sheet and about half of the Laurentide Ice Sheet rested on basement gneiss at their maximum extent (Fig. 1). Gneiss lithologies also comprise around $90 \%$ of the bed of the present-day Greenland Ice Sheet (Henriksen et al., 2000) and a considerable but unquantified part of the East Antarctic Ice Sheet bed (Boger, 2011; Tingey, 1991).

2) Bed topography and roughness have a strong effect on and basal sliding and ice flow near the base of ice sheets and are thus important, but currently poorly constrained, parameters in dynamic ice sheet modelling (Gagliardini et al., 2007; Petra et al., 2012; Schoof, 2005; Weertman, 1957). A better knowledge of subglacial bed roughness, combined with a better understanding of the mechanism(s) of glacier sliding, could therefore significantly reduce uncertainties in future dynamic ice sheet models (e.g. Paterson, 1994). There is increasing evidence for palaeo-ice streams on hard bedrock beds (e.g. Bradwell et al., 2008a; Bradwell, 2013; Eyles, 2012; Roberts and Long, 2005; Stokes and Clark, 2003), which cannot be explained by the 'deforming-bed model', which requires a deforming layer of till to facilitate fast ice sheet flow (e.g. Alley, 1991; Boulton and Hindmarsh, 1987). 


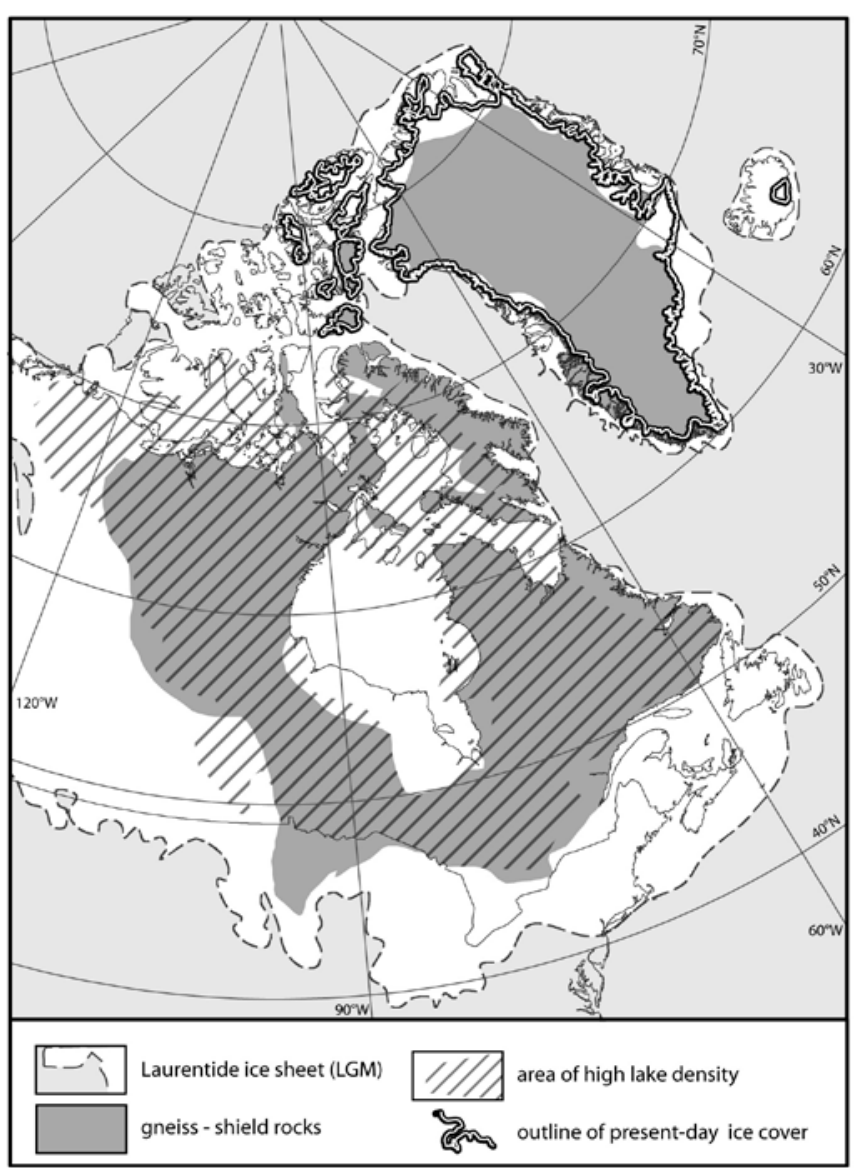

Fig. 1. Laurentide and Greenland ice sheets at the Late Glacial Maximum (after Ehlers and Gibbard, 1994); outcrop of crystalline basement rocks (gneiss and granitic igneous rocks) of the Canadian Shield (after Wheeler et al., 1996) and Greenland (after Henriksen et al., 2000). Zone of medium-high lake density (> 50 lakes per $400 \mathrm{~km}^{2}$ ) after Sugden (1978) and outline of present-day ice cover indicated. Note approximate coincidence of crystalline basement and zone of medium-high lake density.

Unfortunately, bed topography below present-day ice sheets is poorly constrained with only low-resolution bed elevation models currently available (typically >100 m, e.g. Bingham and Siegert, 2009; Fretwell et al., 2013). In contrast, the geomorphology of deglaciated areas can be studied in great detail, especially with increasing availability of high resolution DTM data (e.g. Bradwell 2013; Hubbard et al., 2000; Johansson 1999; Lidmar-Bergström and Näslund 2002; Olvmo et al. 1999). Geomorphological analysis of deglaciated gneiss terrains at different scales can potentially be used as analogues for the subglacial topography of gneiss-dominated beds under present-day ice sheets.

3) The mode of formation of the 'cnoc-and-lochan' landscape is uncertain. Some studies in Scotland, Greenland and Sweden have emphasised the role of subglacial erosion by plucking and abrasion, resulting in innumerable whaleback and roche moutonnée forms (Benn and Evans, 2011; Glasser and Warren, 1990; Gordon, 1981; Rastas and Seppälä, 1981; Rea and Evans, 1996; Roberts and Long, 2005). In contrast, other studies (mainly in Scandinavia) have emphasised the role of deep, pre-glacial weathering and erosion and suggest only a very limited amount of glacial erosion (e.g. Bonow, 2005; Johansson et al., 2001a, b; LidmarBergström, 1989, 1995; Lidmar-Bergström et al., 1997; Lindström, 1988; Olvmo and Johansson, 2002). In southern Sweden, several authors have shown the existence of pre-glacial denudation surfaces (or: etch 
surfaces) of Precambrian, Mesozoic or Tertiary age, with relative relief depending on the time of exposure. Deep weathering, especially in Mesozoic times, has resulted in an irregular weathering front, strongly controlled by joints and fractures. Subsequent stripping left a landscape (an exposed etch surface) that can be either smooth, undulating hilly or possess a multitude of joint-controlled valleys (e.g. Johansson, 1999; Johansson, et al. 2001a, b; Lidmar-Bergström, 1988; 1995; Olvmo and Johansson, 2002; Olvmo et al., 2005). Where Cretaceous cover rocks have been recently removed, for instance in man-made quarries, thick saprolitic weathering mantles with corestones have been documented, as well as small palaeo-hills with shapes similar to roches-moutonnées (e.g. Lidmar-Bergström, 1989, 1995; Lidmar-Bergström et al. 1997; Lindström, 1988). Where Cretaceous cover rocks were removed earlier (possibly in Tertiary times), landforms indicative of deep weathering as a well as remnants of saprolite are locally preserved (Johansson, et al. 2001a,b; Olvmo et al., 1999; 2005). Glaciation in this 'Swedish model' is seen as responsible for stripping the pre-glacial weathering mantle, with only a minor accompanying component of glacial erosion of intact hard bedrock (e.g. Johansson, et al. 2001a, b; Lidmar-Bergström, 1989, 1995; Lidmar-Bergström et al., 1997; Olvmo and Johansson, 2002; Olvmo et al., 2005).

Related to landscape formation is the issue of erosion rates and the total depth of Quaternary glacial erosion integrated over several glaciations. As an example, for the Canadian Shield, some authors have suggested widespread deep (>100 m) glacial erosion (White, 1972; Bell and Laine, 1985), whilst others have suggested rather limited (<50 m) erosion (e.g. Sugden, 1976). Unfortunately, studies using the volume of PlioPleistocene sediments in offshore catchments to estimate the cumulative erosion of shield areas (e.g. Bell and Laine, 1985) cannot easily distinguish between glacial erosion and non-glacial erosion during interglacial periods.

The cnoc-and-lochan terrain can be regarded as a glacial erosional 'hard-bed landform assemblage' (cf. Eyles, 2012). It is increasingly recognised that 'hard-bed landform assemblages' are varied and influenced by bedrock type and structure, the relation between dominant bedrock structure and ice-flow direction, as well as glaciological controls such as ice thickness, ice velocity and thermal regime (Bradwell et al., 2008a; Bradwell, 2013; Eyles, 2012; Gordon, 1981; Johansson et al., 2001a, b; Krabbendam and Bradwell, 2011; Krabbendam and Glasser, 2011; Phillips et al., 2010; Zumberge, 1954).

In a geomorphological study of the 'cnoc-and-lochan' landscape in the gneiss-granite dominated Laxford area of NW Scotland, Bradwell (2013) demonstrated an erosional bedform "zonation” ranging from an absence of glacial erosional forms, via a dominance of stoss-lee forms (e.g. roches moutonnées) to a dominance of abraded forms, with abundant whalebacks and glacial P-forms. The variable intensity of glacial erosion is interpreted to be the result of strong spatial variations in palaeo-ice flow velocity, reflecting the path of the Laxford palaeo-ice stream tributary (Fig. 2, 3) resulting from focussed ice flow between two mountains further upstream. Relevant for gneiss erosion models, Bradwell (2013) showed that: (i) there are significant variations in glacial modification within the overall 'cnoc-and-lochan' landscape, and (ii) that 
higher ice velocities and stronger glacial modification leads to a smoothing and streamlining of a rough landscape.

These conclusions in turn raise the following questions:

1) If strong glacial erosion makes a smoother landscape, why is it that so much glacially eroded gneiss is characterised by a rough landscape?

2) What is the origin of this roughness?

3) What are the controls on the roughness of glaciated gneiss terrains?

In this paper we examine whether the etch-surface hypothesis (the 'Swedish model') is applicable to the classic cnoc-and-lochan landscape in NW Scotland, despite differences in pre-glacial uplift history and glaciological conditions. We present a detailed qualitative analysis of different landform types that together make up the ‘cnoc-and-lochan' landscape of NW Scotland, report occurrences of deep weathering remnants, and analyse the link between weathering remnants, landforms and pre-existing fracture patterns. We then compare the glaciated gneiss landscape of NW Scotland with a gneiss terrain in a non-glacial setting from Namaqualand (Western Cape, South Africa). This comparison is used to constrain the contribution of glacial erosion (the glacial impact) in the formation of different landforms. We discuss the role of the particular bedrock properties of gneiss in the formation of the 'cnoc-and-lochan' landscape and the different controls on the roughness of glaciated gneiss terrains.

\section{Methods and datasets}

Bedrock landforms and bedrock structure in the study area in NW Scotland were studied in a number of field traverses. Fieldwork was augmented by study of othorectified colour air photos and a digital terrain model (DTM) with a vertical and horizontal resolution ca. $1 \mathrm{~m}$ and $5 \mathrm{~m}$ respectively (NEXTMap Britain). All hillshaded DTM images are illuminated from the NW.

We use Schmidt Hammer hardness as a proxy for intact rock strength and fracture spacing as a proxy of rock mass strength (e.g. Aydin and Basu, 2005, Krabbendam and Glasser, 2011). Fractures play an important role during weathering and erosion, and we thus include fracture analysis of a number of localities in our study area. The following terminology is used herein: fracture is used as the general term for any brittle discontinuity in a rock mass. A joint is a fracture without discernible displacement, and is visible on outcrop scale but not on digital terrain models or satellite imagery. A fracture zone is a zone many metres wide, comprising many individual fractures and characterised by a fracture density significantly higher than adjacent rock; fracture zones are visible on remote sensing imagery. Similar features elsewhere have been termed 'master joints' (e.g. Johansson et al. 2001a).

Fracture spacing analysis is based upon the 'circle inventory method' (e.g. Davis and Reynolds, 1996) to prevent any directional bias: outcrop photos were georeferenced in a GIS, creating an 'artificial map' of the outcrop. A 1m grid was superposed on this 'map'. Circles of known area where drawn in the GIS and all fracture traces where digitised within that particular circle. Fracture density (unit: $\mathrm{m}^{-1}$ ) is defined 
as the summed length of all fracture traces divided by the surface area of the circle. Fracture spacing (in m) is the inverse of fracture density (Davis and Reynolds, 1996).

Analysis of the landforms in Namaqualand was performed on an orthorectified monochromatic Landsat ETM+ scene (NASA, 2003) with a pixel resolution of $30 \mathrm{~m}$. At this scale, individual fractures or joints cannot be seen, but fracture zones are visible. For fracture zone analysis we use the same circle inventory method using GIS as the outcrop-scale fracture analysis described above, except at larger scale on the georeferenced satellite image. Rose diagrams of fracture zone orientation used bins of $10^{\circ}$. To prevent bias by a large number of short fracture zones, the summed length of fracture zones within a particular bin is used, instead of the number of fractures. The same fracture zone analysis was also performed on a Landsat scene of part of NW Scotland, with the same $30 \mathrm{~m}$ pixel resolution so as to prevent any bias caused by differences in image resolution.

All mentioned grid references are in British National Grid. Converters to latitude/longitude are available on the web.

\section{North West Scotland - setting}

\subsection{Overall setting and geology}

The study area in NW Scotland is part of the low ground $(<300 \mathrm{~m})$, positioned west of the main watershed (Fig 2, 3). The overall landscape of Northwest Scotland is varied, with a number of different landscape types (Fig. 2A) which have a strong relationship with the underlying bedrock (Krabbendam \& Bradwell, 2010; Lawson, 1995); a summary is given here. The cnoc-and-lochan terrain occurs as a rough peneplain (no genetic connotation implied), ranging from c. $250 \mathrm{~m}$ elevation to below sea level. The area contains the localities described by Linton (1963) and Rea and Evans (1996) as typical areas of 'knock-andlochan' terrain or 'landscape of areal scour'. The cnoc-and-lochan terrain is invariably developed on Archaean-Palaeoproterozoic gneiss, the Lewisian Gneiss Complex (Fig. 2B). The Lewisian gneiss is unconformably overlain by Neoproterozoic sandstone of the Torridon Group and by Cambrian quartzite. Most of the present-day cnoc-and-lochan surface lies well below (>100 m) the Neoproterozoic and Cambrian unconformities (Godard, 1957; British Geological Survey, 2007b).

A number of steep-sided inselbergs rise above the peneplain, reaching 500-800 $\mathrm{m}$ in altitude (Figs. 2C, 3). Most inselbergs are composed of Neoproterozoic sandstone (e.g. Stac Pollaidh, Cul Beag, Suilven). A number of these inselbergs (Cul Mor, Canisp, Beinn Garbh, Quinag) are capped by gently east-dipping strata of Cambrian quartzite (which in turn overlies the Neoproterozoic sandstone) and 

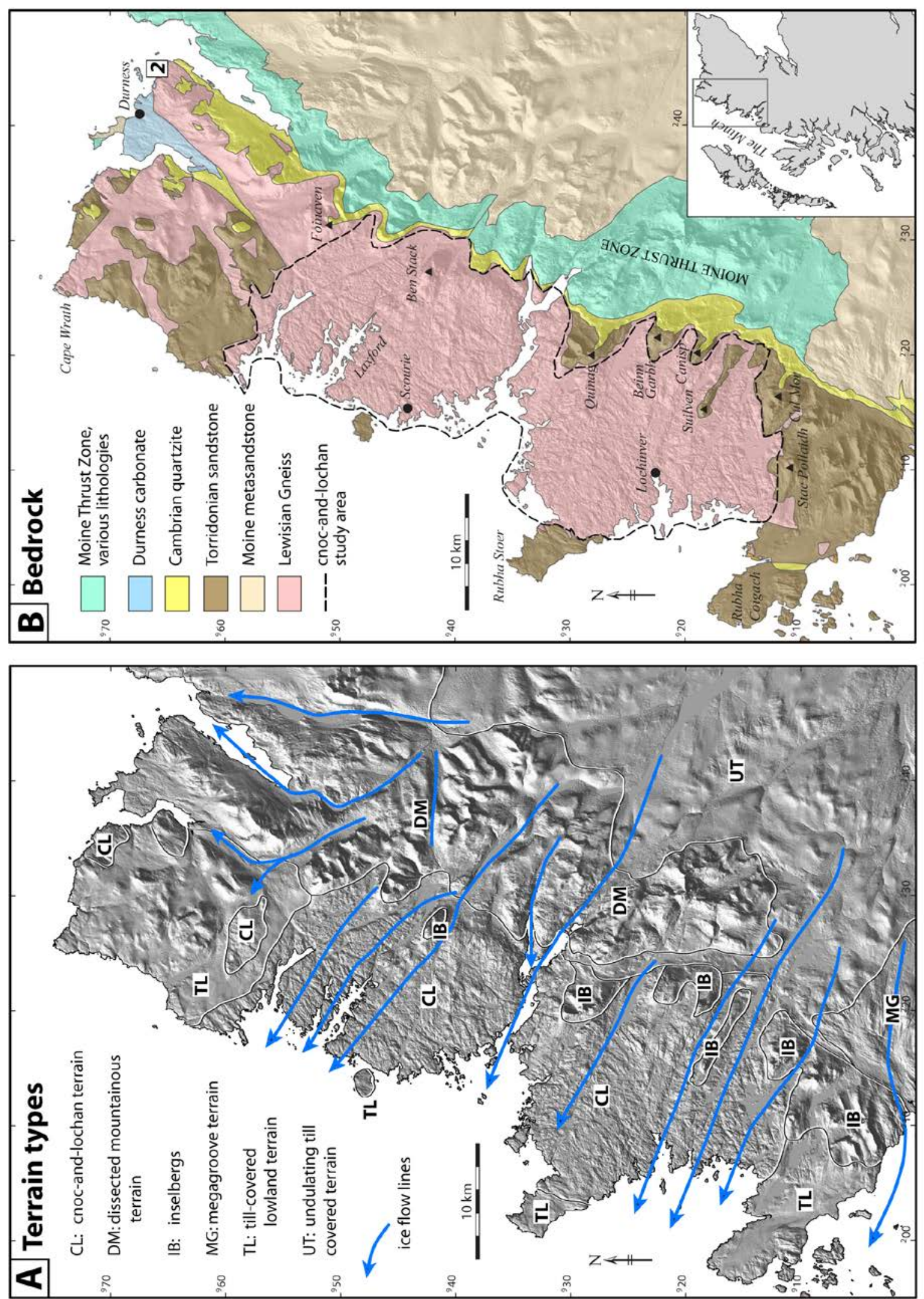

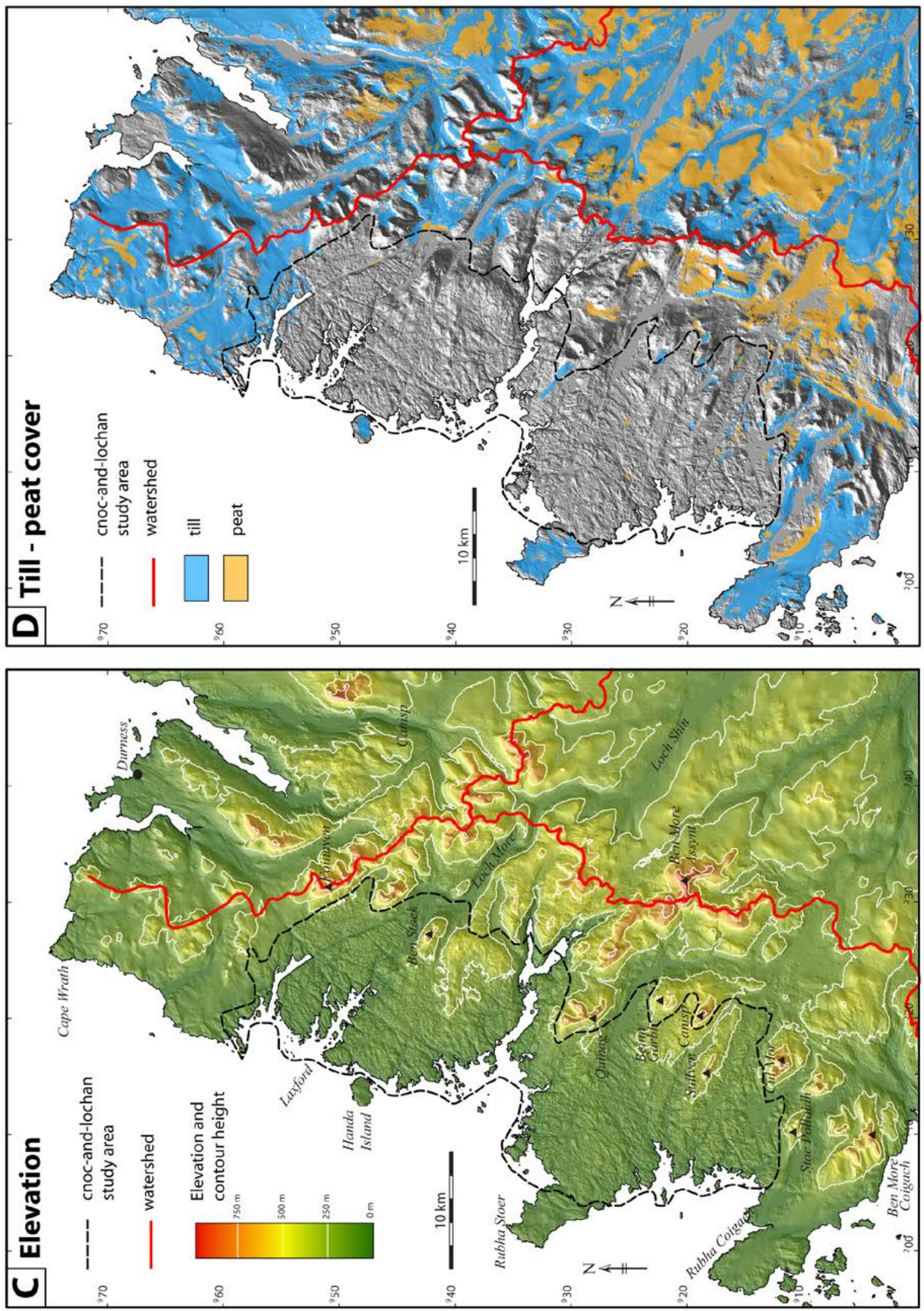

Fig. 2. Setting of study area in NW Scotland. (A) different terrain types and ice flow lines (after Krabbendam and Bradwell, 2010; Bradwell et al., 2008a), (B) simplified bedrock geological map (after British Geological Survey, 2007a); fracture analysis location 2 (Ceannabeinne Beach) is indicated, (C) elevation map, watershed and outline of study area, (D) extend of till and peat cover, derived from DigMap GB (BGS mapping). Patches of cover $<0.1 \mathrm{~km}^{2}$ are not shown. All Figures underlain by hill-shaded relief map derived from NEXTMap data from Intermap Technologies. 
display a pronounced 'flat-iron' shape, showing strong resistance of quartzite to weathering and erosion. One inselberg (Ben Stack, $721 \mathrm{~m}$ high) is entirely composed of Lewisian Gneiss.

The peninsulas of Rubha Coigach, Rubha Stoer and Cape Wrath as well as Handa Island are also underlain by Neoproterozoic sandstone (Figs. 2B, 3). These areas are typified by gently undulating, smooth terrain with few lake basins. Till cover is extensive on these headlands (Fig. 2D), and most till west of the watershed occurs on this terrain (Krabbendam \& Bradwell 2010).

To the east, the area is bounded by dissected mountainous terrain up to $950 \mathrm{~m}$ high, hosting the present-day drainage divide (Fig. 2C). This mountainous terrain is typified by ridges, corries and glacial valleys. Some flat-topped mountains are covered by extensive block fields and other periglacial features (e.g. Ballantyne 1995); steeper mountains have arêtes, bounded by corries or glacially widened valleys. Some glacial valleys continue westward as fjords (Loch Glencoul, Loch Glendhu) showing a component of strongly focussed erosion (Fig. 3). Along Loch More, a glacial valley system has breached the main watershed. The corries and some higher valleys of NW Scotland were occupied by ice during the Younger Dryas glaciers (e.g. Benn and Lukas, 2006; Lawson 1986; Bradwell 2006). The mountainous terrain broadly follows the Caledonian Moine Thrust Zone (Fig. 2B), a zone of tectonic thrust slices of highly variable lithologies including hard Lewisian gneiss, Cambrian quartzite and Cambro-Ordovician dolostone with weaker siltstones (e.g. Peach et al. 1907; Krabbendam and Leslie 2010).

East of the mountains lies an undulating terrain, dominated by Moine metasandstone and schist. Most of this ground shows an extensive till cover (Figs. 2B, D), except in the south where a scoured terrain of megagrooves has developed caused by palaeo-ice stream erosion (e.g. Bradwell et al. 2008a; Krabbendam \& Bradwell 2011).

To the west, the study area is bounded by the Minch Basin, which contains a thick sequence of Permo-Triassic to Jurassic sediments, followed by a thin sequence of Cretaceous and Tertiary sediments and a thin cover of Quaternary glacial, glacio-marine and marine sediments (e.g. Stein 1992; Morton 1992; Fyfe et al. 1993). The uplift history of NW Scotland is complicated and closely linked to the subsidence history of the Minch Basin. Some four phases of subsidence and uplift during the Mesozoic and Cenozoic have been recorded by apatite fission-track dating in the west of Scotland (Holford et al. 2010). It is possible the study area was inundated and partially covered by marine sediments during the late Mesozoic, but any such sedimentary rocks have disappeared since. Hall (1991) suggests that the present-day large-scale topography of NW Scotland, including the summit height approaching $1000 \mathrm{~m}$ and the cliff retreat now characterising the steeper west-facing topography of NW Scotland, was largely established during the Tertiary. 


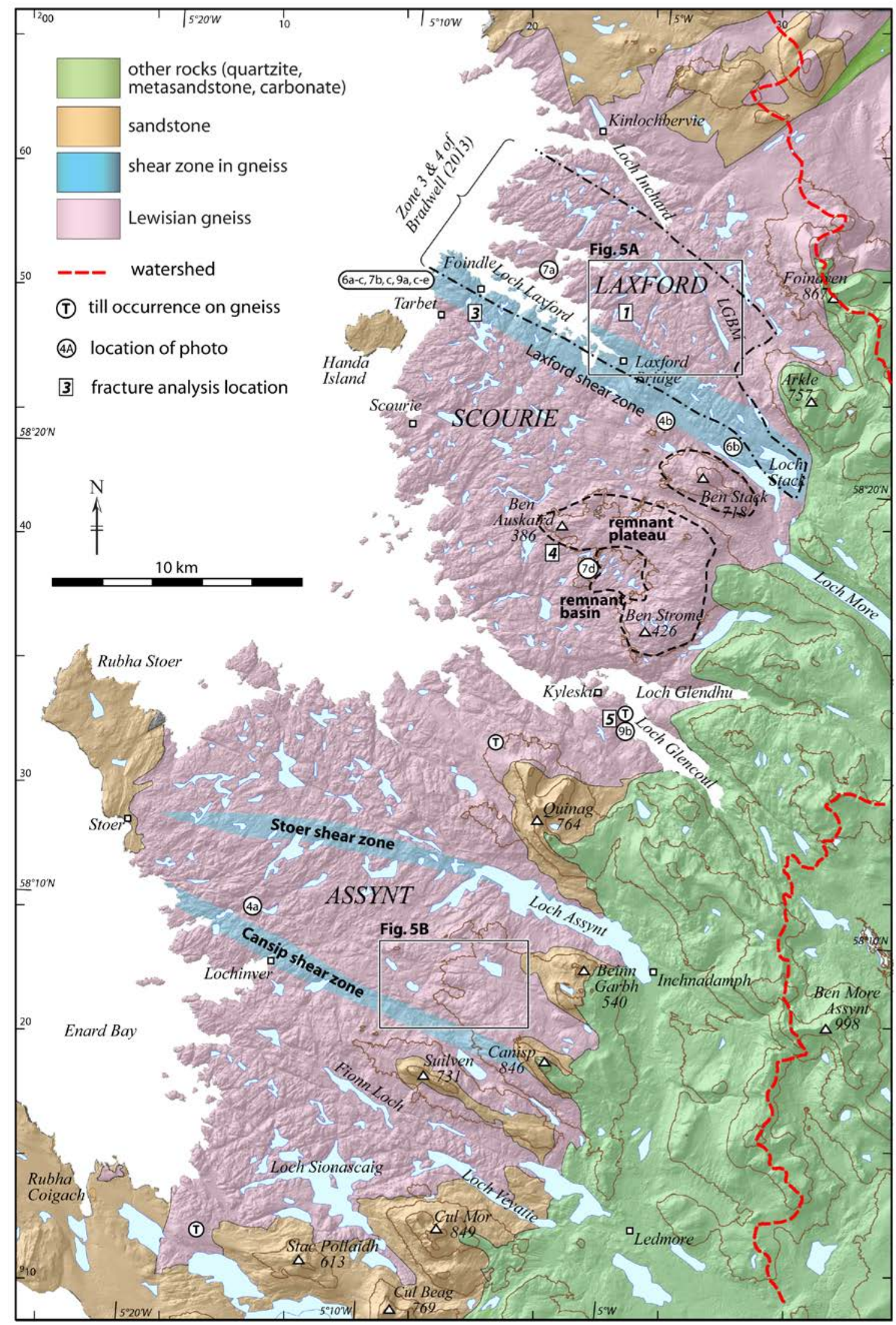

Fig. 3. Overview of study area: overlain by simplified bedrock geological map (after British Geological Survey, 2007a). Zone 3 and 4 of Bradwell (2013) with streamlined-dominant landforms, interpreted as the Laxford Palaeo-ice Stream Tributary. Boxes indicate location of Figs. 5A, 5B, 11. Location of till occurrences, photos and fracture analyses are indicated. Contour interval $250 \mathrm{~m}$. DTM derived from NEXTMap data from Intermap Technologies. LGBM = Loch a’ Garbh-bhaid Mor. 

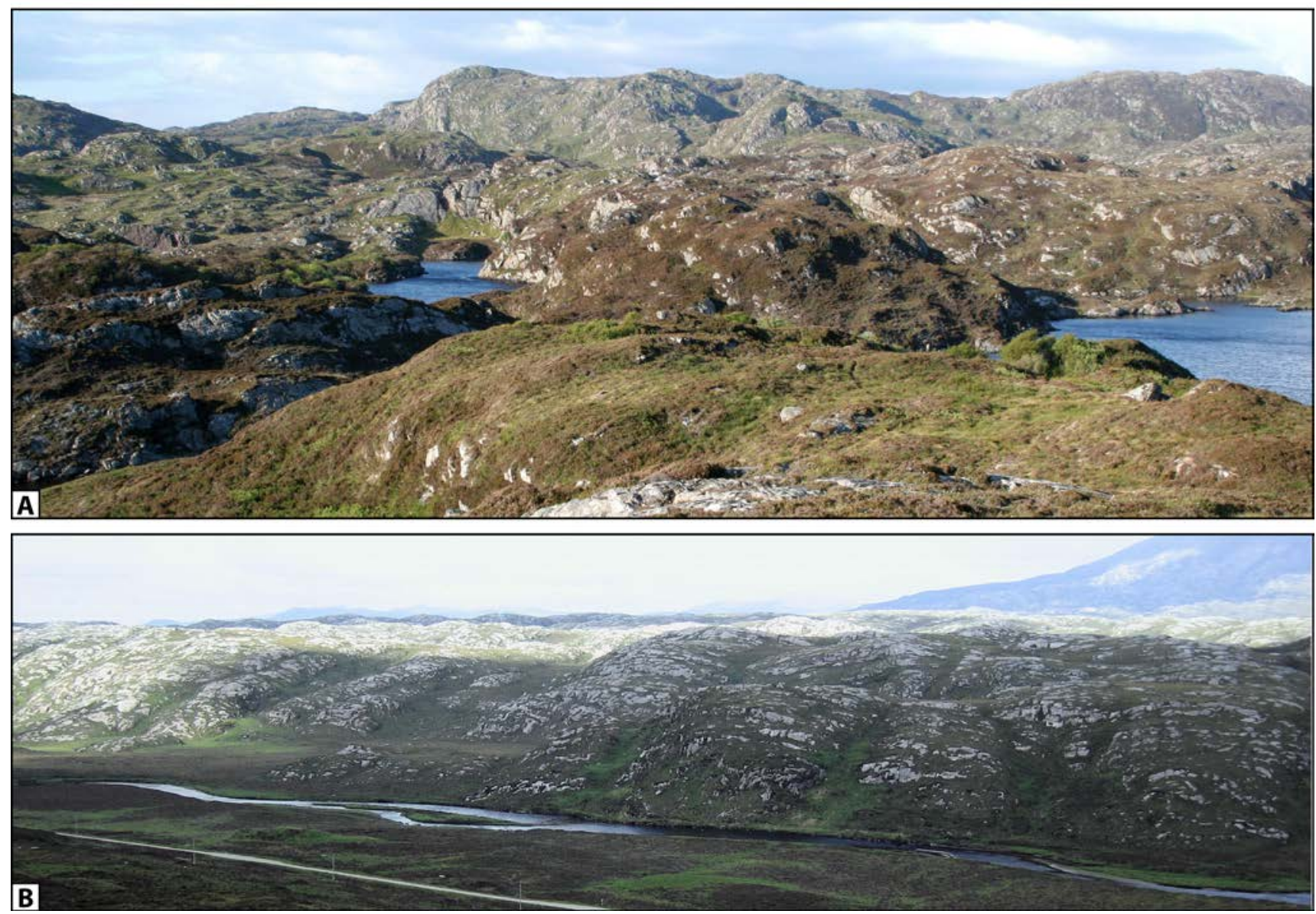

Fig. 4. Overview field photographs of cnoc-and-lochan landscape of different roughness (A). Typical rough cnoc-andlochan landscape, north of Lochinver. BGS Photo P856904. (B). Smoothed cnoc-and-lochan landscape in Laxford area. View northward, across Laxford River; palaeo-ice flow from right to left. Height of features above river is $\sim 70 \mathrm{~m}$. 2 km NW of Ben Stack [NC 26 44], BGS photo P856717

\subsection{Glaciological setting}

Scotland was repeatedly glaciated during the Pleistocene. Each major glaciation in NW Europe resulted, depending on its severity, in a large ice cap or ice sheet forming over western Scotland. At least 12 major cold periods in the last $\sim 2.6$ Ma probably led to ice-sheet growth Scotland; in a number of glaciations ice reached the edge of the continental shelf. The glaciations of Marine Isotope Stages 12 and 4-2 were particularly intense and long lived, both lasting $>50 \mathrm{ka}$, and probably including several phases of ice sheet advance and retreat (Hubbard et al., 2009; Lee et al., 2012;Shackleton et al., 1984; Stoker et al., 1993). During the Devensian (=Weichselian/Wisconsinan) glaciation, the main ice divide in the northern Highlands was located east of the present-day watershed (Read et al., 1926); this was also presumably the case for preceding glaciations of similar severity. Ice-sheet flow in NW Scotland was thus generally from east to west (Fig. 2A), with zones of fast ice flow directed through major gaps in the watershed (Stoker and Bradwell, 2005; Bradwell et al., 2007; Bradwell, 2013). Evidence of westward ice flow in the study area is supported by mapped glacial striae and erratic dispersal patterns (Lawson, 1990, 1996; British Geological Survey, 2013; Bradwell, 2013). 

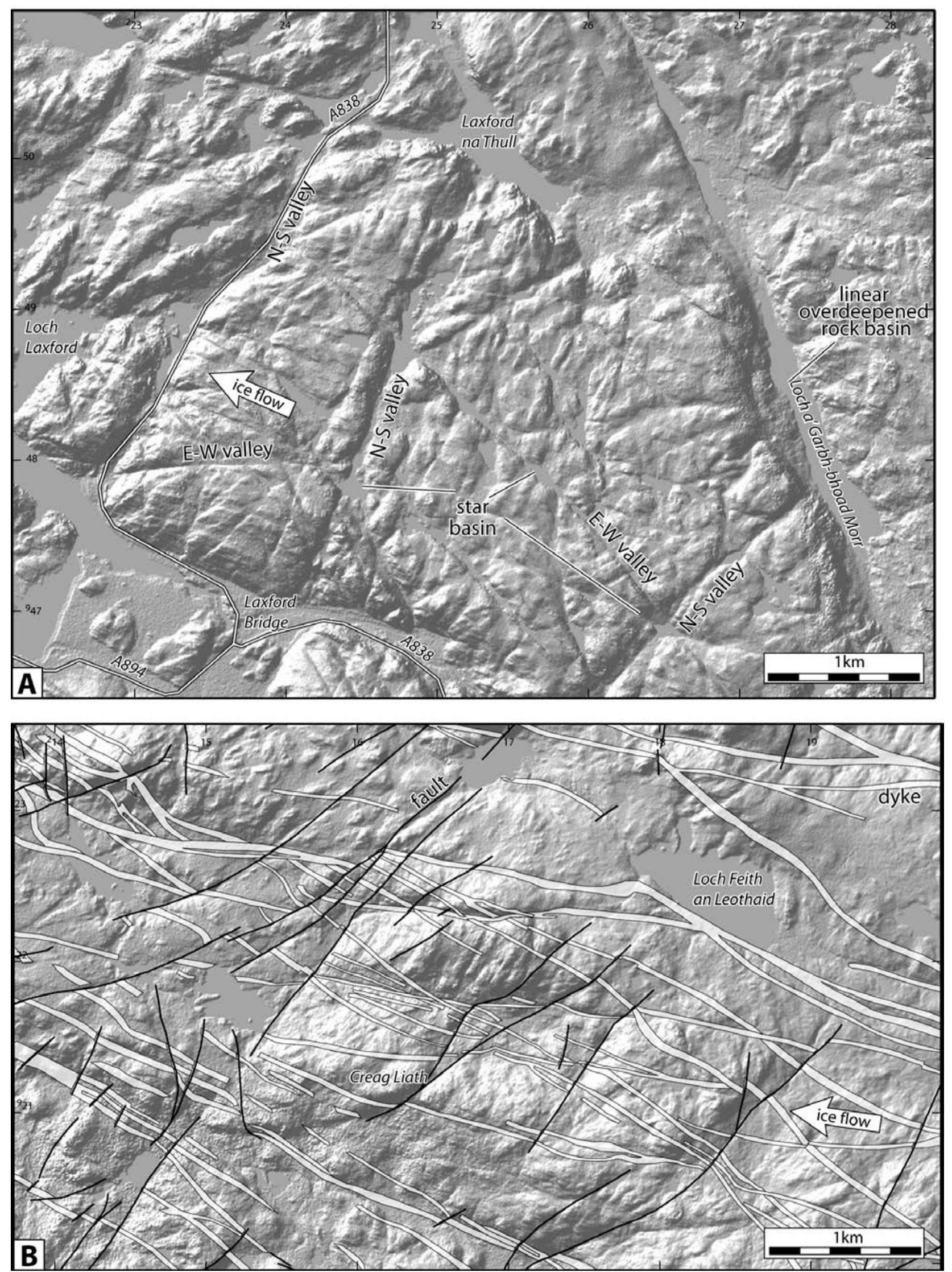

Fig. 5. Hill shaded DTM images, located on Fig. 3. (A). Laxford area. Some large-scale landforms are indicated and discussed in text. Ice flow indicated. (B). Cnoc-and-lochan landscape, SW of Loch Assynt, with Scourie Dykes (white) and faults or fracture zones (black lines) superimposed (after British Geological Survey, 2007b). Note predominant east-west orientation of dykes and coincidence of many dykes with linear valleys. DTMs derived from NEXTMap data from Intermap Technologies 
Cosmogenic isotope exposure ages show that high elevation areas (> $800 \mathrm{~m}$ ) had deglaciated by $\sim 16 \mathrm{ka}$ BP (Fabel et al., 2012). However, the timing of Late-Devensian deglaciation of the low ground is still debated and is the subject of continuing research (Bradwell et al., 2008b; Stoker et al., 2009; Ballantyne and Stone, 2011). Glaciation during the Younger Dryas (13-11 ka BP) resulted in the development of ice caps and local cirque glaciers on high ground, but ice cover at this time did not reach the low ground within the study area (Lawson, 1986; Benn and Lukas, 2006; Bradwell, 2006).

\section{Landforms of glaciated gneiss terrain: North West Scotland}

The Lewisian gneiss of mainland NW Scotland is characterised by a rugged landscape of countless rockbasins or lochans and rock hills or cnocs (from Gaelic) - the classic cnoc-and-lochan terrain (Figs. 3, 4, 5). This terrain occurs on a rough peneplain up to about 250 m ASL (Fig. 2C). Relative relief varies between about 20-30 m in some areas such as Laxford, to 50-80 $\mathrm{m}$ in rougher areas around Scourie and Lochinver (Fig. 3). Very little till occurs (Fig. 2D); the rare till occurrences are described in detail below. Upstanding quartz veins suggest that post-glacial (post Late Devensian) subaerial weathering amounts to $10-20 \mathrm{~mm}$, sufficient to remove most glacial striae, but showing that the medium-scale landforms have been little modified since deglaciation. The occurrence of striae (indicating little or no post-glacial weathering) is relatively rare (Lawson, 1996; Bradwell, 2013) but striae are seen on gneiss surfaces protected from postglacial weathering by soil, peat or water.

\subsection{Roche moutonnées, whalebacks, P-forms.}

Medium-scale bedforms such as roche moutonnées and whalebacks are ubiquitous throughout the area (Fig. 6A, B). Typically they are 2-10 m high, and 5-50 m long. Roche moutonnées show the classic distinct asymmetry - a smooth rounded stoss-side and a jagged plucked lee-side. Plucking generally exploits preexisting joints in the gneiss in the manner described by Rea (1994), Krabbendam and Glasser (2011) and Hooyer et al. (2012). In most of the area, roche moutonnées are more common than whalebacks, but this is reversed in the Laxford area. In this area, smoothed landforms with abraded lee-sides are more common than plucked ones, despite the ubiquitous presence of joints (Fig 6C). Bradwell (2013) provides a quantitative analysis of the relative distribution of whalebacks and roche moutonnées. P-forms occur but their distribution is patchy, although they are notably more common in the Laxford zone (Bradwell, 2013). P-forms typically occur on the lateral sides of whalebacks or roche moutonnées, parallel to east-west palaeoice flow (Fig. 6D). 

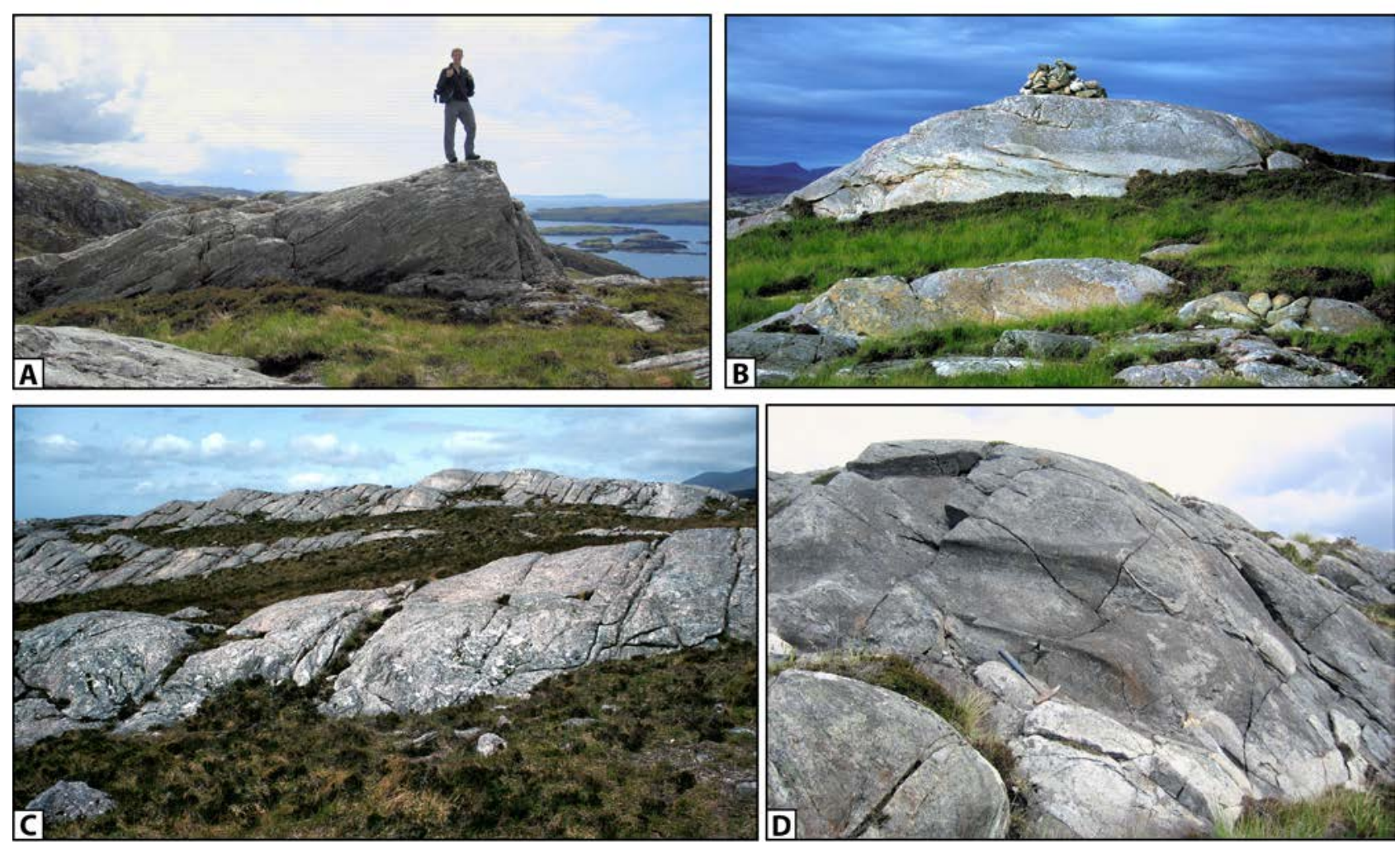

Fig. 6. Medium-scale bedrock landforms in Lewisian Gneiss, NW Scotland.

(A) Classic roche moutonnée, with smoothed, abraded stoss-side and plucked lee face. View to the south, ice flow from left to right. $1 \mathrm{~km}$ north of Tarbet; [NC1660 5008], BGS photo P856752.

(B) Whaleback with smooth, abraded stoss- and lee-side. View to the north, ice flow from right to left. Cairn on top is man-made. Summit of Creag na Fionndalach, 1 km east of Foindle; [NC 1968 4865]; BGS photo P576869.

(C) Series of smooth low-angle whalebacks. Note absence of plucking, despite presence of joints at right angle to palaeo-ice flow. View to the north, ice flow from right to left. North of Loch Stack; [NC 2802 4386]; BGS photo P571432.

(D) P-forms on lateral face of whaleback; minor plucked faces at top. View to the north, ice flow from right to left. Cnoc Gorm, north of Tarbet; [NC1672 4984], BGS photo P576835.

\subsection{Streamlined hills.}

This term is used for larger (> $100 \mathrm{~m}$ long) hills. Overall, the shape of these hills resembles a whaleback, but the hills themselves are composed of tens of individual nested whalebacks, each 5-50 m long (Fig. 7A).

Much of the 'peneplain' north of Laxford Bridge is composed of such composite whalebacks. Streamlined hills are separated by linear valleys of varying depth and width, described below.

\subsection{Linear valleys}

Numerous narrow, linear valleys (Figs. 7B, C) are clearly visible on the hill-shaded 5-m resolution DTM (Fig. 5). These range in length from 0.5 - $20 \mathrm{~km}$, are typically 10-20 m deep, and between 50-200 m wide. Many linear valleys contain strings of small lakes and/or small streams. The linear valleys typically follow fracture zones or Scourie Dykes, but are not developed along single joints. The linear valleys in NW Scotland are similar but wider than the clefts in Sweden reported by Olvmo \& Johansson (2002) which appear to follow single joints, but narrower than the joint-bounded valleys or fissure valleys reported by Rudberg (1973) and Lidmar-Bergström (1995). 

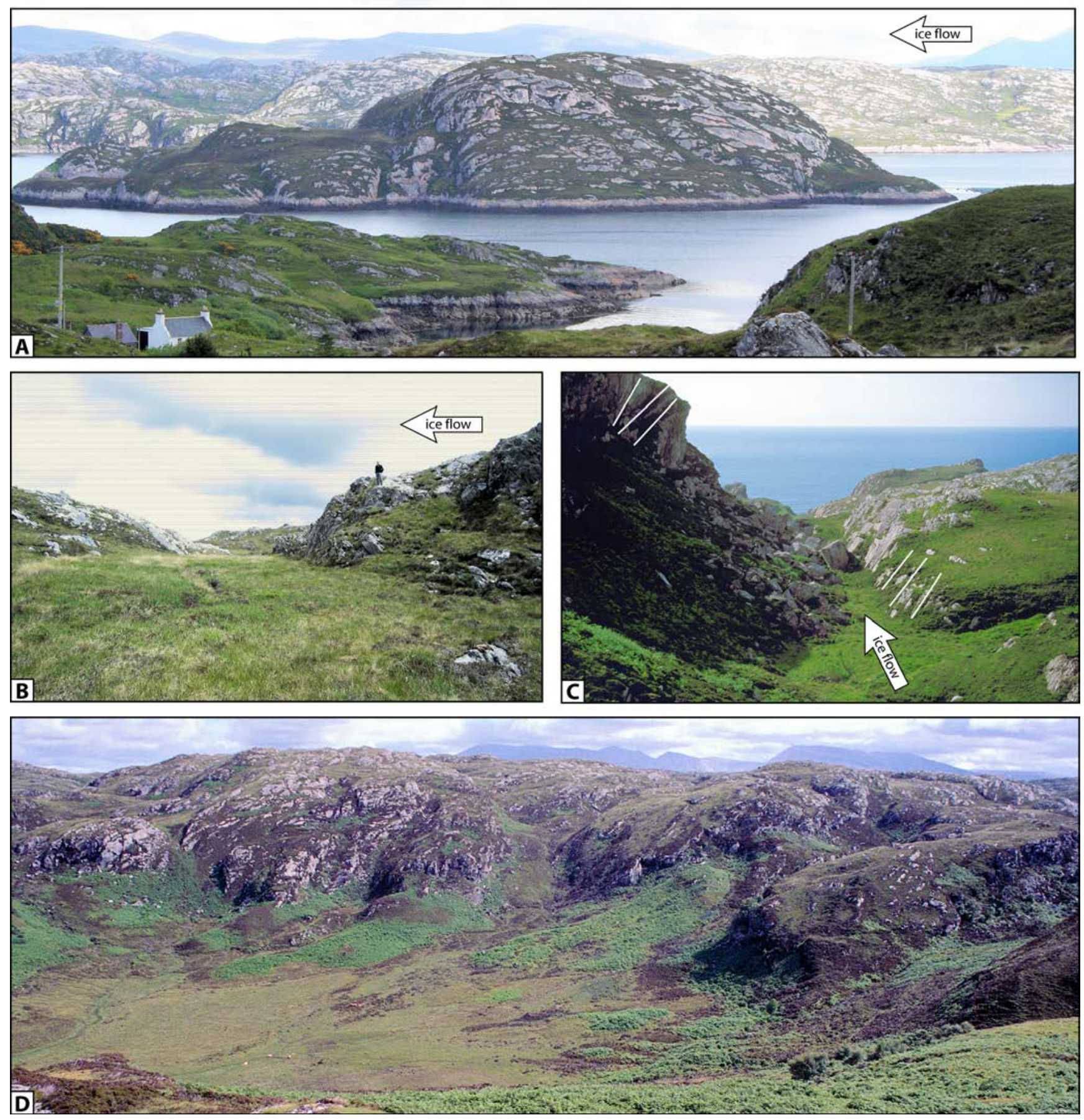

Fig. 7. Large-scale landforms in Lewisian Gneiss, NW Scotland. Palaeo-ice flow indicated.

(A) Streamlined hill with smooth and gentle dipping stoss-side; steep and partially smoothed lee-side, within path of Laxford palaeo-ice stream. View to north. Eilean Ard; Loch Laxford. [NC 18 50], BGS photo P856923.

(B) North-south trending linear valley, partially filled with peat. View to north. 1 km north of Tarbet. [NC1645 4995], BGS photo P856746

(C) WNW-ESE trending linear valley. View to west, along palaeo-ice flow. Note asymmetry linked to bedrock fractures (marked by white lines), and tumbled blocks below north-facing cliff. North of Tarbet [NC 1650 4962], BGS photo P576850.

(D) Large-scale depression; depth c. 100 m, width of basin c.2 km. 3 km north of Kylesku [NC 23 38]; outline indicated on Fig. 3. BGS photo P576929.

North-south trending linear valleys, oriented at high angles to ice flow (Fig. 7B), are commonly asymmetric in cross profile with a smoothed western side ('stoss-side' with respect to palaeo-ice flow) and a rugged, 
blocky eastern-side ('lee-side'), suggesting dominant abrasion and plucking processes respectively across the linear valley. The eastern-sides are typically 5-15 m high cliffs, up to several hundred metres long. These blocky cliffs are commonly higher than the individual joint spacing, suggesting the cliffs have formed by multiple plucking events.

East-west trending linear valleys, oriented sub-parallel to ice flow, are generally steeper and deeper than north-south trending linear valleys (Fig. 7C). Many east-west trending linear valleys are asymmetric, with one side wall steeper (or even overhanging) than the other, with the asymmetry controlled by the dip of the local fracture system. Gently dipping side walls are commonly abraded, whilst steep side walls are rugged and locally punctuated by small post-glacial rock falls, especially where the dominant cliff-parallel fracture set results in oversteepened or overhanging walls.

\subsection{Star-shaped lakes}

A number of star-shaped lakes, or star-shaped rock basins, occur throughout the area (Fig. 5). These are irregularly shaped lakes without elongation, but with multiple 'arms'. These star-shaped lakes occur at the intersection of two or more deep linear valleys. The linear valleys now function as stream valleys that enter the lake from different directions. On the field traverses, no damming by glacial or post-glacial deposits was seen, and the lakes do represent true rock basins.

\subsection{Troughs, lakes and fjords parallel to ice flow}

A number of large-scale linear troughs occur throughout the area, forming overdeepened linear rock-cut lake basins inland (Loch Veyatie, Fionn Loch, Loch Assynt, Loch a' Garbh-bhaid Mor), and deep inlets or fjords at the coast (Loch Glencoul, Loch Laxford, Loch Inchard) (Fig. 3). These troughs and linear basins are broadly parallel with WNW-ENE bedrock structures (Lawson, 1995; Krabbendam and Bradwell, 2010). More specifically, Loch Laxford is aligned to the composite Laxford Shear zone (Goodenough et al., 2010), Loch Assynt is partly aligned with the Stoer Shear Zone and the brittle Loch Assynt Fault (Krabbendam and Leslie, 2010) and Loch Inchard and Loch a' Garbh-bhaid Mor are aligned along the WNW-ESE trending Loch Inchard normal fault (Pless, 2011) (Figs. 3, 5A). However, some overdeepened basins such as the Loch Glencoul-Glendhu fjord system are not associated with a major shear zone or fracture zone, and appear to lack a specific structural control. Conversely not all shear zones are associated with major troughs: the Canisp Shear Zone (Attfield 1987) has no appreciable negative topographical expression.

\subsection{Remnant basins and hills}

Although the cnoc-and-lochan landscape is dominated by small wavelength $(<200 \mathrm{~m})$ topographic features, a number of larger scale features occur. These include a number of residual hills, the highest of which is Ben Stack (721 m). Just to the south is a crescent shaped plateau, at about 400-500m elevation (Ben Auskaird and Ben Strome on Fig. 3), partly enclosing a remnant basin some $2 \mathrm{~km}$ across (Fig. 7D). It is possible that this large-scale remnant topography dates back to the Neoproterozoic (albeit in strongly modified form), since it is known that the Torridon Group was deposited on a hilly landscape, and a $400 \mathrm{~m}$ high 
Neoproterozoic palaeo-hill can be mapped out within Quinag, south of Kylesku (e.g. Peach et al. 1907; British Geological Survey, 2007b; Stewart 2002).

\subsection{Till cover}

The Lewisian gneiss terrain is dominated by bedrock outcrop and is notable for its virtual lack of till (Fig. 2D). Till occurrences on gneiss are typically restricted to small patches ( $<50 \mathrm{~m}$ across) between cnocs or in linear valleys and gorges. A small till patch exposed in a roadside cutting SE of Kylesku [NC 2350 3208] (Fig. 3) comprises up to $6 \mathrm{~m}$ thickness of till, partly infilling an linear valley between two ice-moulded gneiss outcrops. The till overlies a zone of fractured and weathered Lewisian gneiss, with as much as $30 \%$ of the rock mass comprising weak, friable weathered rock and saprolite. Till clast lithology is exclusively gneiss; many clasts are composed of weathered, friable gneiss, attesting to local derivation. No clasts of lithologies further upstream (e.g. Cambrian quartzite) were found. Some till occurs in narrow zones or 'tails' downstream of inselbergs of Torridon sandstone (e.g. Stac Pollaidh, Quinag, Fig. 3) these tills are dominated by sandstone clasts, and were clearly sourced from sandstone mountains (see Stoker and Bradwell, 2011, for the same feature further south). It appears that till deposition was limited by a lack of subglacial debris, and till deposition only occurred on or close to friable, mechanically weak bedrock.

\section{Lewisian gneiss: structure, fractures, weathering}

The large- and medium-scale landforms within the cnoc-and-lochan landscape are strongly influenced by the underlying structure, in particular brittle structures such as joints and fracture zones (see also Lawson, 1995). The relation between linear valleys and fracture systems has been noted in southern Sweden (e.g. Johansson, 1999; Johansson et al. 2001a; Olvmo and Johansson 2002; Rudberg 1973). To understand this link between fracturing and erosional landforms, we analysed the fracture pattern in the Lewisian Gneiss. The Lewisian Gneiss Complex comprises a range of rock types generated between c. 3000 and 1600 million years ago (Park, 2005), including tonalitic and granodioritic gneisses, with minor amounts of mafic and ultramafic rocks and pegmatitic granite. Gneiss contains a pronounced layering of coarse-grained minerals, but the granoblastic texture of interlocking crystals means that in unweathered gneiss this layering does not represent a significant mechanical anisotropy: unweathered gneiss is thus mechanically a 'massive' rock. Schmidt Hammer hardness of unweathered Lewisian gneiss is in the range of 55-60, in line with gneisses elsewhere (eg. Deere and Miller1966; Irfan and Powell, 1985).

The Lewisian gneiss was intruded by hundreds of mafic and ultramafic dykes between $10-100 \mathrm{~m}$ thick, subsequently metamorphosed to amphibolite, the so-called Scourie Dyke Suite, dated between 24002000 Ma (e.g. Heaman and Tarney, 1989). South of Loch Laxford, the original dyke geometry is well preserved and shows a clear WNW-ESE trend (Fig 5B). North of Loch Laxford, the dykes are strongly deformed and occur in irregular shapes (Goodenough et al., 2010). Scourie Dykes are normally finergrained than the surrounding gneiss, with very fine-grained chilled margins. 


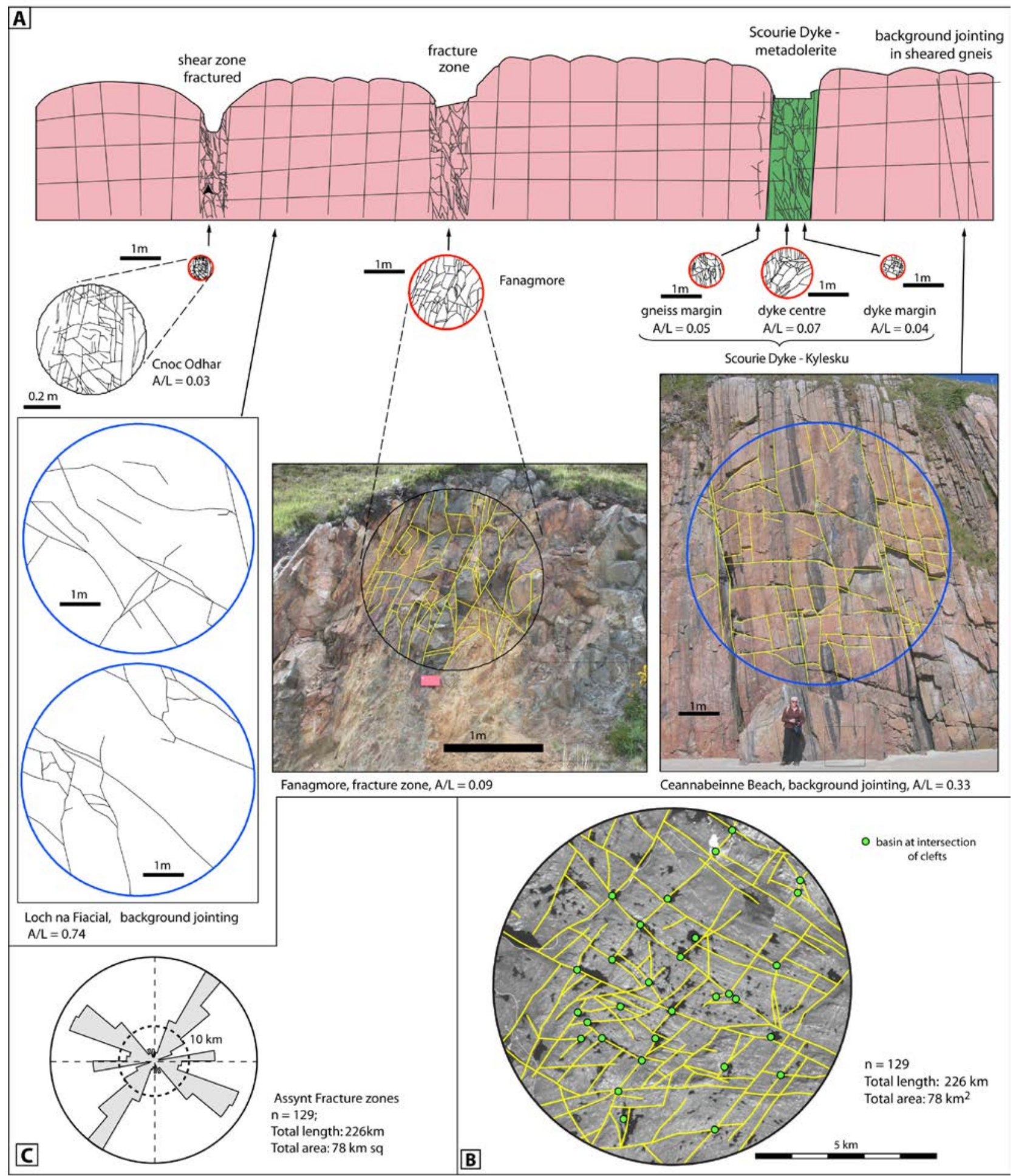

Fig. 8. Joint and fracture zone analysis in Lewisian Gneiss, NW Highlands.

(A) Overview of joint analysis of Lewisian Gneiss. Sketch shows schematically background jointing, subvertical and intense jointing in fracture zones and Scourie Dykes, indicating the great variety in joint spacing. Circles show joints digitised from georeferenced field photos; two field photos are given as an example. Loch na Fiacial and Ceannabeinne Beach represent background jointing; all other localities are fracture zones. All circles at same scale, except where expanded (Fanagmore and Cnoc Odhar). AL is joint spacing in m. See Table 1 for data and location detail; locations also shown on Figs 2 and 3.

(B). Fracture zone analysis on panchromatic Landsat scene . NASA Landsat 8 OLI scene LC82060192013201LGN00 and LC82060202013201LGN00, 20 July 2013, Orthorectified (GLS2000). Image courtesy of U.S. Geological Survey. Processed by K.B. Smith, BGS (C). Rose diagram showing orientations of fracture zones, digitised as in (B). 
The Lewisian gneiss cooled below c. $400^{\circ}$ at c. 1500 Ma (e.g. Cliff et al., 1998) and has been accumulating brittle fractures ever since (Beacom et al., 2001; Pless, 2011). Tectonic events causing fracturing included at least three rifting events (Stoer Group rifting at c. 1200 Ma; Iapetus rifting at c. 600 Ma; Atlantic rifting from c. 65 Ma onwards) as well as two major mountain building episodes (Grenvillean, 1100 - $1000 \mathrm{Ma}$; and Caledonian, 440-420 Ma) (Trewin, 2002; Woodcock and Strachan, 2002; Ellis et al., 2012). The vast majority of fractures thus pre-date glaciation, but repeated glaciation and deglaciation may have further opened some fractures. For the purpose of this study, structures are subdivided into joints and fracture zones. Joints are (single) fractures without displacement (e.g. Davies and Reynolds, 1996). Fracture zones are linear zones of dense fracturing.

\subsection{Jointing}

Single, small-scale $(<20 \mathrm{~m}$ long) joints are ubiquitously present throughout the Lewisian gneiss (see also Pless, 2011 for a detailed study). This 'background' jointing is represented in Fig 8A by the Loch na Facial and Ceannabeinne Beach localities, which joint spacing of $0.33 \mathrm{~m}$ and $0.74 \mathrm{~m}$ respectively (Table 1), although joint spacing and orientation varies greatly throughout the study area (Pless, 2011). Joints play a major role in glacial plucking (Rea, 1994; Krabbendam and Glasser, 2011; Hooyer et al., 2012) and many plucked faces coincide with joints (e.g. Fig 6A, D). However, whalebacks without plucked faces may nonetheless contain several joints (eg. Fig 6C). The single background joints do not coincide with and are not responsible for the linear valleys visible on the DTM.

\subsection{Fracture zones}

Fracture zones (but not single joints) have been exploited by erosion to form linear valleys visible on the NEXTMap DTM and Landsat imagery (Figs 3, 5, 8B). Pless (2011) mapped over 4000 fracture zones in the area shown in Figure 3. Fracture zones vary in length of several $100 \mathrm{~m}$ to up to $20 \mathrm{~km}$ (between Loch Stack and Kinlochbervie, Fig. 3). The circle inventory method applied on a Landsat 7 scene gives an average fracture zone spacing of $350 \mathrm{~m}$. (Note that the spacing of fracture zones and linear valleys visible on the DTM will be smaller, as many fracture zones are smaller than the resolution of Landsat imagery). The width of individual fracture zones varies from 1-100 m. Orientation analysis (rose diagram; Fig 8C) from the Scourie area shows two dominant sets: one trending NE-SW and one trending WNW-ESE, with a subsidiary east-west trending set. In the Assynt and Laxford areas, NNW-SSE to NW-SE fracture zones also occur. Overall, the fracture zones delineate a pronounced criss-crossing pattern with multiple intersections, delineating blocks with rectangular or triangular shapes (Fig. 5, 8B). 


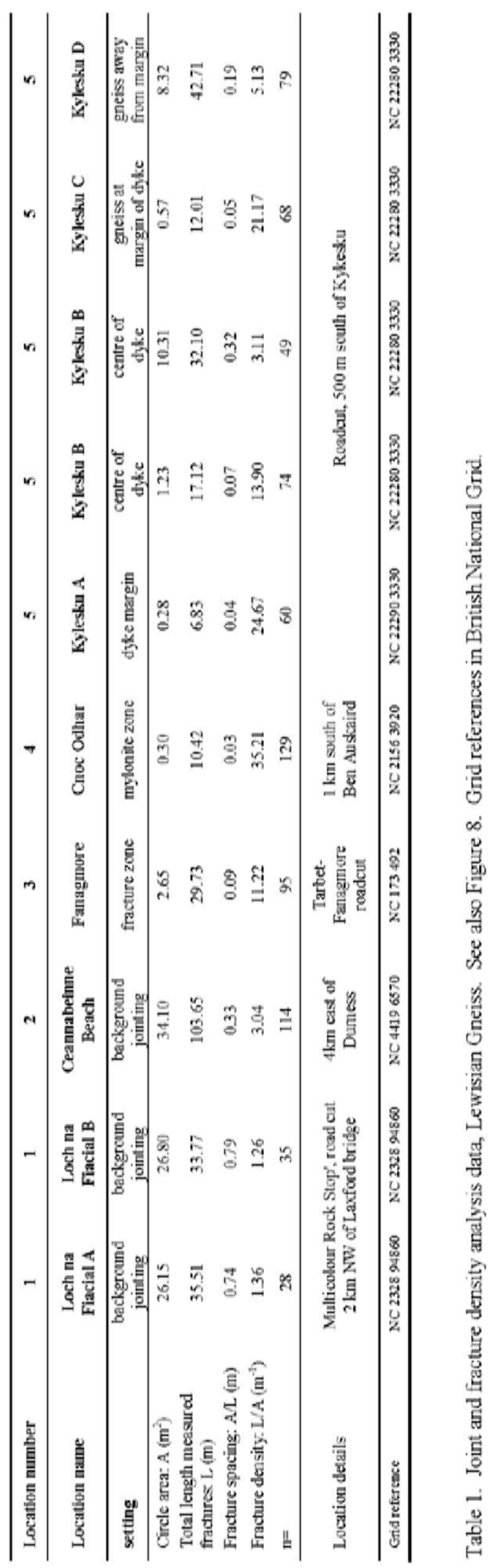


Fracture zones occur broadly in three settings (Fig. 8A):

1) Fracture zones related to older, pre-existing ductile shear zones. Numerous ductile shear zones occur within the Lewisian gneiss; they are typically steep and trend WNW-ESE (subparallel to former ice flow). They vary in width from less than $1 \mathrm{~m}$ to up to 1-3 km for named shear zones (Fig. 3) such as the Stoer Shear Zone and the Canisp Shear Zone (e.g. Attfield, 1987). Compared to normal gneiss, sheared gneiss has a schistose or mylonitic foliation, and has a finer grain size (less than $1 \mathrm{~mm}$ as opposed to 2-5 mm). Original feldspar and pyroxene minerals have been partially or wholly replaced by mica and amphibole minerals (Attfield, 1987).

Altogether, this results in a softer, mechanically much weaker rock. In addition, shear zones are generally more intensely fractured than the adjacent gneiss (e.g. Pless, 2011) and commonly contain 'ladder' fractures, with fracture spacing as close as 10-100 mm (e.g. Beacom et al., 2001). One such dense fracture pattern has been analysed at the 'Cnoc Odhar' locality (Fig. 8A), where average fracture spacing is $0.03 \mathrm{~m}$ (Table 1).

2) Fracture zones related to Scourie Dykes also trend WNW-ESE. Many Scourie Dykes are coincident with kilometre-long linear valleys, some 5-20 m deep and typically of the same width as the dyke itself (Fig. 5B, 8A). Schmidt Hammer hardness is similar (50-60) to that of gneiss, so difference in hardness cannot explain the preferential formation of linear valleys along the trace of the dyke. One c. $100 \mathrm{~m}$ wide dyke south of Kylesku at [NC 2280 3332] was studied in some detail (Fig. 8A). The intact gneiss away from the dyke has a fracture spacing of c. $0.2 \mathrm{~m}$ (Table 1). Adjacent to the dyke is a 4-5 m wide zone of fractured gneiss, in which the fracture spacing decreases to $0.05 \mathrm{~m}$. On its northern margin this fractured gneiss also exhibits a zone of weathered, mechanically weak or 'rotten' rock. The outer margins of the dyke itself are marked by a 4-5 m wide zone of densely fractured metadolerite, with a fracture spacing of $0.04 \mathrm{~m}$. In the centre of the dyke, the fracture spacing increases to c. 0.07 to $0.3 \mathrm{~m}$ (Fig. 8A; Table 1). Thus, the fracture spacing and hence the rock mass strength of the dyke is lower than in intact gneiss, with the margins of the dyke characterised by even closer fracture spacing and lower rock mass strength.

3). Fracture zones unrelated to older features. These fracture zones have a variety of orientations, but most N-S to NE-SW trending fracture zones do not follow pre-existing features. The fractures are probably related to extensional rifting events (Mesoproterozoic rifting related to Stoer group deposition and Atlantic rifting, e.g. Trewin et al. 2002) as a number of NE-SW trending normal faults with significant displacement occur in the area (British Geological Survey, 2007b; Stewart, 2002).

In summary, the Lewisian gneiss consists of 'blocks' of relatively coherent rock, possessing ubiquitous single joints with wide spacing (0.3-0.7 m), separated by a network of criss-crossing fracture zones within which fracture spacing is an order of magnitude smaller (0.03-0.09 $\mathrm{m})$ than the 'background' joint spacing (Table 1, Fig 8A). It is the fracture zones (and not the joints) that have been exploited by differential weathering and subsequent erosion to form linear valleys. This is somewhat different from the typical uniform joint patterns and joint spacing that is commonly portrayed in geomorphological studies related to 

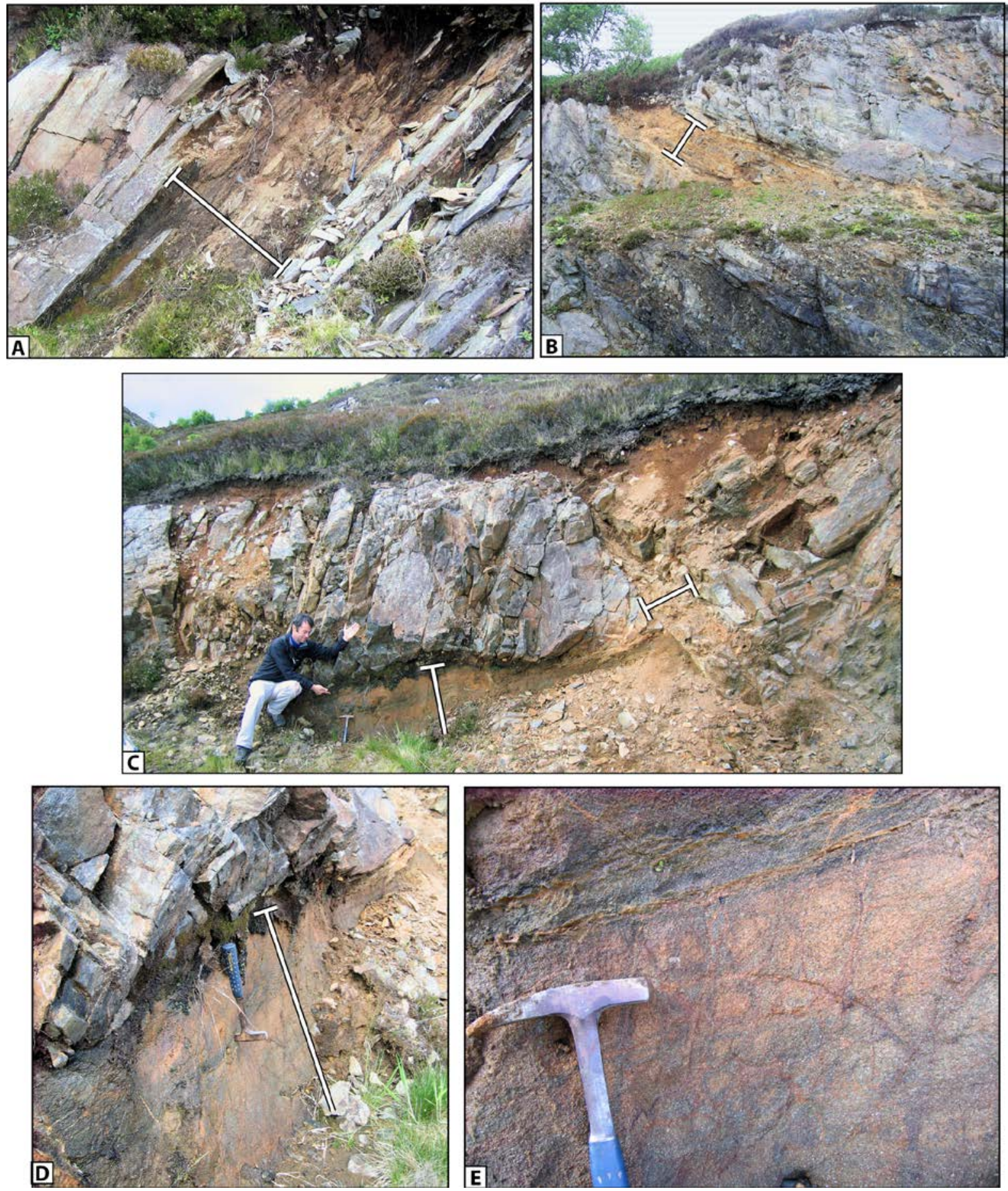

Fig. 9. Remnants of deep weathering (marked by white bars) in Lewisian Gneiss - see text for more detailed description.

(A) Deeply weathered layer between sound bedrock with some fracturing. Tarbet-Fanagmore Road, [NC 173 493], BGS photo 8856766.

(B) Fracture zone (north-dipping) in Lewisian Gneiss, with sandy saprolite in upper part. Roadcut, 1 km SE of Kylesku, [NC 2373 3255] BGS photo P856821.

(C) Deep weathering along steep and gentle dipping fracture zone. Note weathering beneath sound but fractured rock. Foindle -Fanagmore Road, [NC 1862 4874] BGS photo P856726.

(D) Detail of C. Clayey saprolite, easily penetrated by hammer below sound bedock. BGS photo P856720.

(E) Coherent granular saprolite with relict texture of iron-stained fractures. Near C. BGS photo P856724. 
granite weathering and erosion (e.g. Ollier, 1984; Twidale, 1982), although a similar arrangement between joints and larger scale fracture zones or discontinuities has been documented by Shaw (1997) in the Kowloon Granite in Hong Kong.

\subsection{Deep weathering remnants}

Remnants of deep pre-glacial weathering have been found in a number of places in the study area (Fig. 9). A steeply dipping zone, c. $0.5 \mathrm{~m}$ wide, along the Tarbet-Fangamore road consists of clayey saprolite in the centre, flanked by granular saprolite ('grus') at the margins; sharply bounded by sound but fractured bedrock (Fig. 9A). Nearby, along the same road, a fracture zone is seen to have undergone sulphuric alteration, attesting to secondary fluid infiltration and indicating the first stages of deep weathering.

A clear link between fracture zones and enhanced weathering was also found in a road cut section south of Kylesku (Fig. 9B). Here, a c. $10 \mathrm{~m}$ wide fracture zone (itself following an earlier shear zone) dips c. $30^{\circ}$ to the north. A c.1 m wide zone of yellow-brown sandy saprolite and weathered rock occurs in the centre of the fracture zone. A small patch of till partially covers this fracture zone.

Some $500 \mathrm{~m}$ west of Foindle, saprolite was found in a fracture network comprising both vertical and horizontal zones (Figs. 9C, D, E). The steep fracture zone contains sandy saprolite. The subhorizontal zone of saprolite (Figs. 9C, D) is c. $1 \mathrm{~m}$ thick and occurs below intact gneiss and amphibolite. This weathered zone consists of granular saprolite with a central zone of clay, which can be easily penetrated with a rock hammer pick, attesting to very low rock strength. In granular saprolite, relict gneissic layering and locally relict fractures with iron staining are also seen (Fig. 9E).

Remnants of deep weathering in the Lewisian gneiss all occur within fracture zones, showing that deep rock weathering was facilitated by infiltrating fluids via enhanced access along pre-existing fracture zones. Weathering remnants associated with single joints have not been found. Thus all weathering remnants occur well below (> $10 \mathrm{~m}$ ) the local summit levels of the 'cnocs'. This suggests that the 'saprock' zone of weathered bedrock along single joints, that typically leads to onion-skin weathering and corestones in many granite or gneiss dominated areas (e.g. Migoń, 2006; Lidmar-Bergström, 1989, 1995; Ollier, 1984; Tvidale, 1982; Shaw, 1997; Setterholm and Morey, 1995) is not present (anymore) in the Lewisian gneiss of the study area.

\section{Landforms of non-glaciated gneiss terrain: Namaqualand, South Africa}

\subsection{Introduction to non-glaciated gneiss terrains}

Studies of weathering mantles and the nautre of the weathering front in both glaciated and non-glaciated gneiss terrains have typically relied on exposures in road cuts, quarries, river-sections and boreholes. These studies have shown that the weathering front is typically highly irregular (e.g. Anand and Paine, 2002; Lidmar-Bergström et al., 1997; Lindström, 1988; Shaw, 1997; Thomas, 1966; Twidale, 2002). To examine the glacial vs. non-glacial impact on exposed gneiss terrains as a whole, one would ideally examine an etch surface in a non-glaciated gneiss terrain that is exposed over a large area. Finding such exposed etch 
surfaces is non-trivial, since many gneiss shield areas are typically still covered by a thick weathering mantle, or by alluvial and aeolian deposits (e.g. Fairbidge and Fink, 1980; Anand and Paine, 2002) or, in the case of areas with a low 'free-board', covered by marine deposits as a result of global transgressions during the Early Palaeozoic or the Cretaceous (e.g. Miller et al. 2005). Other gneiss terrains have been uplifted but subjected to fluvial incision: such terrains show dendritic drainage landscapes that have in effect destroyed the etching surface; an example is the eastern escarpment of Madagascar, composed of Archaean and Proterozoic gneiss (Goodwin, 1996).

One gneiss terrain that does appear to possess a well-preserved, exposed etching surface is Namaqualand, Western Cape, South Africa. The Namaqualand gneiss is composed of high-grade metaigneous gneisses and granitic rocks, largely formed by c. 1000 Ma (Jackson, 1979; Robb et al., 1999). The Namaqualand gneiss terrain now occurs on a c. $1000 \mathrm{~m}$ high plateau, above the 'Great Escarpment' that characterises the margin of south-western Africa (e.g. Brandt et al. 2005; Gilchrist et al., 1994; Kounov et al. 2009). The area has been uplifting, at variable rates, since the rifting of southern Africa and South America in the Early Cretaceous, with a major phase of uplift and denudation during the Mid-Cretaceous, as indicated by the off-shore sediment record and apatite fission-track analyses (e.g. Kounov et al., 2009; Luft et al., 2005; Rust \& Summerfield, 1990). Denudation rates were markedly lower after the Late-Cretaceous, and the present-day topography of the high plateau was probably broadly established by that time (De Wit 1999; Gilchrist et al., 1994; Kounov et al. 2009). During the Cainozoic; kaolonitic saprolite developed under humid conditions, with calcrete or silcrete duricrusts development under drier conditions (Brandt et al. 2005; De Wit 1999; McCarthy et al. 1985). A change from humid to arid conditions occurred probably during the Late-Miocene, and an arid or semi-arid climate has been prevalent in south-western Africa for at least 10 million years, whilst the area has not been subjected to Pleistocene glaciation (De Wit, 1999; Siesser, 1980; Ward et al., 1983; van Zinderen Bakker and Mercer, 1986). The gently sloping Bushmanland Plateau east of the gneiss outcrop is covered by a thin veneer of alluvial and aeolian deposits of ?late-Cretaceous, Cainozoic through to Quaternary age, overlying weathered gneiss (McCarthy et al. 1985; de Wit 1999; Brandt et al. 2003; 2005). Stripping of the Namaqualand gneiss terrain apparently occurred by aeolian and fluvial erosion by small ephemeral rivers, but evidently did not lead to deep fluvial incision. 


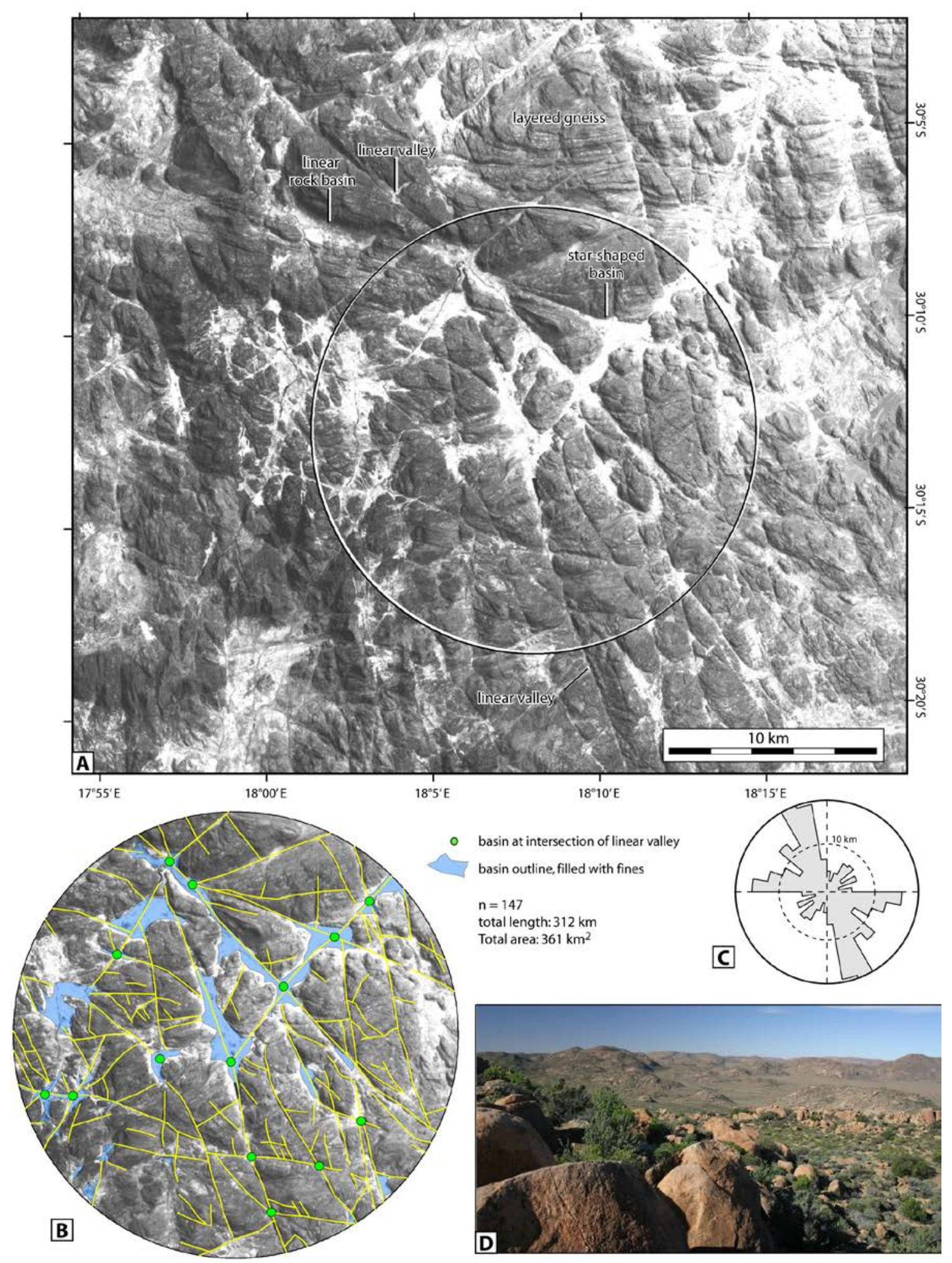

Fig. 10. (A) Panchromatic Landsat image of part of Namaqualand, South Africa. Note star-shaped basins (filled with fine material); linear basins and valleys in a variety of orientations. Analysed circle is $20 \mathrm{~km}$ across. NASA Landsat 7 ETM+ scene LE71760812003052EDC01, 21 February 2003, SLC-off, Level 1T Orthorectified (GLS2000). Image courtesy of U.S. Geological Survey. Processed by K.B. Smith, BGS.

(B) Mapped clefts (following fracture zones - blue lines), deposits of fines (yellow) and intersections (green dots). Further discussed in text.

(C) Rose diagram of clefts / fracture zones. Bins of $10^{\circ}$. using total length of fracture within a bin.

(D) View of landscape in Namaqualand, showing numerous round hills. Note abundant round boulders (freed corestones) present. Goegap Nature Reserve, 11 km east of Springbok, South Africa (29³9’S, 1759’E). Photo courtesy of Dr. Thomas Wagner. 


\subsection{Landforms - Namaqualand}

An analysis of the Namaqualand gneiss terrain was made on a panchromatic Landsat scene, covering some $1600 \mathrm{~km}^{2}$, with a more detailed fracture zone analysis in a circle covering $360 \mathrm{~km}^{2}$ (Fig. 10). The following landforms can be observed. The area is dominated by bare bedrock, comprising a rough landscape of numerous hills and knolls. The knolls are separated by linear valleys that criss-cross the landscape. The length of linear valleys varies from less than a kilometre to over $30 \mathrm{~km}$ (Fig. 10A). The linear nature of the valleys indicates that they coincide with large fracture zones; some of these have been interpreted as faults by Kounov et al. (2009). These fracture zones evidently represent weaker rock that has been eroded more deeply than adjacent, less densely fractured rock. Tracing of fracture zones and GIS analysis (Fig. 10B) showed that a total length of $312 \mathrm{~km}$ of fracture zones occurs within a circle of $360 \mathrm{~km}^{2}$ (Table 2), indicating an average spacing of c. $1.1 \mathrm{~km}$. A rose diagram (Fig. 10C) of fracture zone trends shows two main clusters (at $100-280^{\circ}$ and $160-340^{\circ}$ ) some $60^{\circ}$ apart, as well as some smaller clusters. This broadly bimodal pattern is similar (albeit with different orientation) to the fracture zone pattern in the NW Scotland study area.

\begin{tabular}{lcc}
\hline & NW Scotland & Namaqualand \\
\hline Total circle area $\left(\mathrm{km}^{2}\right)$ & 78 & 361 \\
Total fracture length $(\mathrm{km})$ & 226 & 312 \\
Fracture zone density $\left(\mathrm{km}^{-1}\right)$ & 2.9 & 0.86 \\
Fracture zone spacing $(\mathrm{km})$ & 0.35 & 1.15 \\
$\mathrm{n}=$ & 129 & 147 \\
\hline
\end{tabular}

Table 2. Fracture zone analysis data from on Landsat imagery for the Lewisian gneiss in NW Scotland and Namaqualand. See Fig 8B and 10B for study areas.

The white to light grey patches seen on the monochromatic Landsat image are interpreted as fine grained material: deposits of sand or silt or remnant saprolite, or a combination of these. These are mapped within the circle. Many deposits of fines occur at intersections of two or more linear valleys /fracture zones (Fig. 10B); these basins are star-shaped with branches following some distance along individual linear valleys.

The knolls themselves are cut by narrower lineaments (again most likely following narrower fracture zones) at a spacing of c. $10-50 \mathrm{~m}$. These fractures are visible as they support vegetation (presumably because they are filled with fine sediment or saprolite) or because they have been eroded out into narrow clefts. A larger and wider linear rock basin occurs in the NW part of the area Fig. 10A. In the northern part of the image, a number of bedrock ridges can be seen, which are absent in the remainder of the scene. This is probably caused either by a better developed gneissic layering within the gneiss in the northern part of the image, or by a different (more flat-lying) orientation of that layering making it more prone to differential erosion and thus having a clearer expression in the landscape. Either way, numerous clefts and linear valleys with associated fracture zones continue from the layered to the non-layered gneiss. 
A fieldphoto (Fig. 10D) taken by T Wagner in the Goegap Nature Reserve in Namaqualand, shows a rugged landscape with numerous rounded hills, separated by basins. Round boulders of locally derived rock are abundant (unlike NW Scotland) and are interpreted as freed corestones, a common feature of many granite landscapes (Migoń, 2006; Thomas, 1965; Twidale, 1982;).

\section{Discussion and implications}

The comparison of the landforms of NW Scotland and Namaqualand (Table 3) shows that many landforms occur in both areas. Common landforms include: hills and knolls on a variety of scales, linear valleys, long rock ridges, large linear rock basins and star-shaped rock basins. The majority of medium-to-large scale $(>5 \mathrm{~m})$ landscape features in both landscapes are similar, and this indicates that these features cannot exclusively of glacial origin; this emphatically included closed rock basins (see also Johansson et al. 2001b; Rudberg, 1973). Exceptions are streamlined hills and overdeepened linear rock basins that only occur in NW Scotland and are likely to be formed at least partially by some form of glacial erosion. This comparison is consistent with previous work on glaciated granite-gneiss terrains Scandinavia and Greenland (e.g. Bonow, 2005; Lidmar-Bergström, 1989, 1995; Lindström, 1988; Olvmo et al. 1999).

\begin{tabular}{lccc}
\hline & NW Scotland & Namaqualand & Glacial Origin? \\
\hline Linear rock basins & yes & yes & no \\
Star-shaped rock basins & yes & yes & no \\
Linear valleys & yes & yes & no \\
Hills, knolls & yes & yes & no \\
Streamlined hills & yes & no & yes \\
Long bedrock ridges & yes & yes & no \\
P-forms, roche moutonnées & yes & no & yes \\
Overdeepened linear & yes & no & yes \\
rock basins & & & \\
\hline
\end{tabular}

Table 3: Comparison of landforms on gneiss in NW Scotland and Namaqualand

\subsection{Deep weathering as a starting point}

Flat lying gneiss shield terrains are typically subjected to long term (>> 1myr) deep weathering (e.g. Anand and Paine, 2002). Deep weathering is a mainly chemical process strongly dependent on fluid access, which is facilitated by a mature fracture zone network (e.g. Nesbitt and Markovics, 1997; Shaw, 1997). Over time, weathering produces a thick saprolite blanket or weathering mantle, with a highly irregular weathering front strongly controlled by the fracture zone network (e.g. Kroonenberg and Melitz, 1983; Thomas, 1966) (Fig. $11 \mathrm{~A})$. The weathering zone typically contains a zone of core-stones, but weathering along fracture zones can proceed much deeper (Shaw, 1997). Fracture analysis in the Lewisian gneiss shows that the fracture zones can contain saprolite at deeper levels than adjacent unweathered rock (Figs. 8, 9). Deep weathering along fracture zones, an irregular weathering front and the formation of core stones controlled by a broadly 
orthogonal joint system are well known features of long-term, deep weathering of granite and gneiss terrains in temperate and tropical weathering zones (e.g. Anand and Pain, 2002; Kroonenberg and Melitz, 1983; Nesbitt and Markovics, 1997; Ollier, 1984; Shaw, 1997; Thomas, 1966; Twidale, 2002). In glaciated areas, thick saprolite mantles have been preserved below for instance Cretaceous cover rocks, as documented in Minnesota, USA (Setterholm and Morey, 1996) and in southern Sweden (Lidmar-Bergström 1989; LidmarBergström et al. 1997; Olvmo et al. 2005). Such pre-Cretaceous weathering profiles on gneiss and granite are up to $60 \mathrm{~m}$ thick and characterised by an upper zone of clayey (kaolinitic) and/or granular saprolite and a lower zone of saprolite mixed with core stones, with a very irregular weathering front. In northern Europe, remnants of deep weathering have been found in NE Scotland, Sweden and Finland (Hall, 1985; Hall and Mellor, 1988; Elvhage and Lidmar-Bergström, 1987; a good overview is provided by Migoń and LidmarBergström, 2001). This suggests that deep long-term weathering producing deep saprolite has also occurred in gneiss and other rock-types at higher latitudes.

In Namaqualand and NW Scotland, we suggest that the weathering mantle was stripped, but by different erosional processes. In Namaqualand, saprolite was most likely stripped by wind, rain and minor fluvial erosion (Fig. 11B, C); it is notable that large boulders (core stones freed from surrounding saprolite) are still present, strewn across the landscape (Fig. 10D). The 'starting point' for glacial erosion in the Early Pleistocene in NW Scotland, and other gneiss terrains affected by Pleistocene ice-sheet glaciation, was most probably a deeply weathered gneiss terrain covered in saprolite and with a highly irregular weathering front (Fig. 11A). This conclusion is further supported by the occurrence of remnant saprolite in fracture zones in NW Scotland (this study), southern Sweden (Elvhage and Lidmar-Bergström 1987; Johansson et al., 2001a, b; Olvmo et al., 2005); Greenland (Bonow, 2005) and Quebec and Adirondacks (Bouchard et al., 1995).

\subsection{Variability of glacial modification}

In light of the above, we propose that much of the cnoc-and-lochan landscape in NW Scotland corresponds approximately to the pre-glacial weathering front, similar to that described in southern Sweden (Johansson et al., 2001a, b; Lidmar-Bergström, 1995, 1997; Olvmo et al., 2005; Olvmo and Johansson, 2002). Stripping of saprolite would most likely have occurred during the first major glacial cycle(s) in the early Pleistocene. Saprolite has very low intact and mass rock strength (Fig. 12; see also Irfan and Powell, 1985) and can be efficiently denuded by both glacial as well as fluvioglacial erosion processes. Most saprolite was probably removed rapidly by the mechanical action of an (re)advancing ice sheet, and the flushing action of high energy glacial melt water streams. The relative rarity of saprolite remnants (normally confined to protected locations) in deglaciated gneiss terranes in Scotland, Scandinavia and Canada (this study, Elvhage and Lidmar-Bergström 1987; Olvmo et al., 2005; Bouchard et al., 1995) compared with the widespread occurrence of saprolite in similarly tectonic stable gneiss terrains of Africa, Australia or South America (e.g. Anand and Pain, 2002; Bárdossy and Aleva, 1990; Brandt et al. 2005; Fairbridge and Finks, 1980; Kroonenberg and Melitz, 1983) suggests that ice-sheet glaciation is a very effective method of removing saprolite. The resultant landscape after the first glaciation would then closely resemble the pre-glacial weathering front (Fig. 11E). 


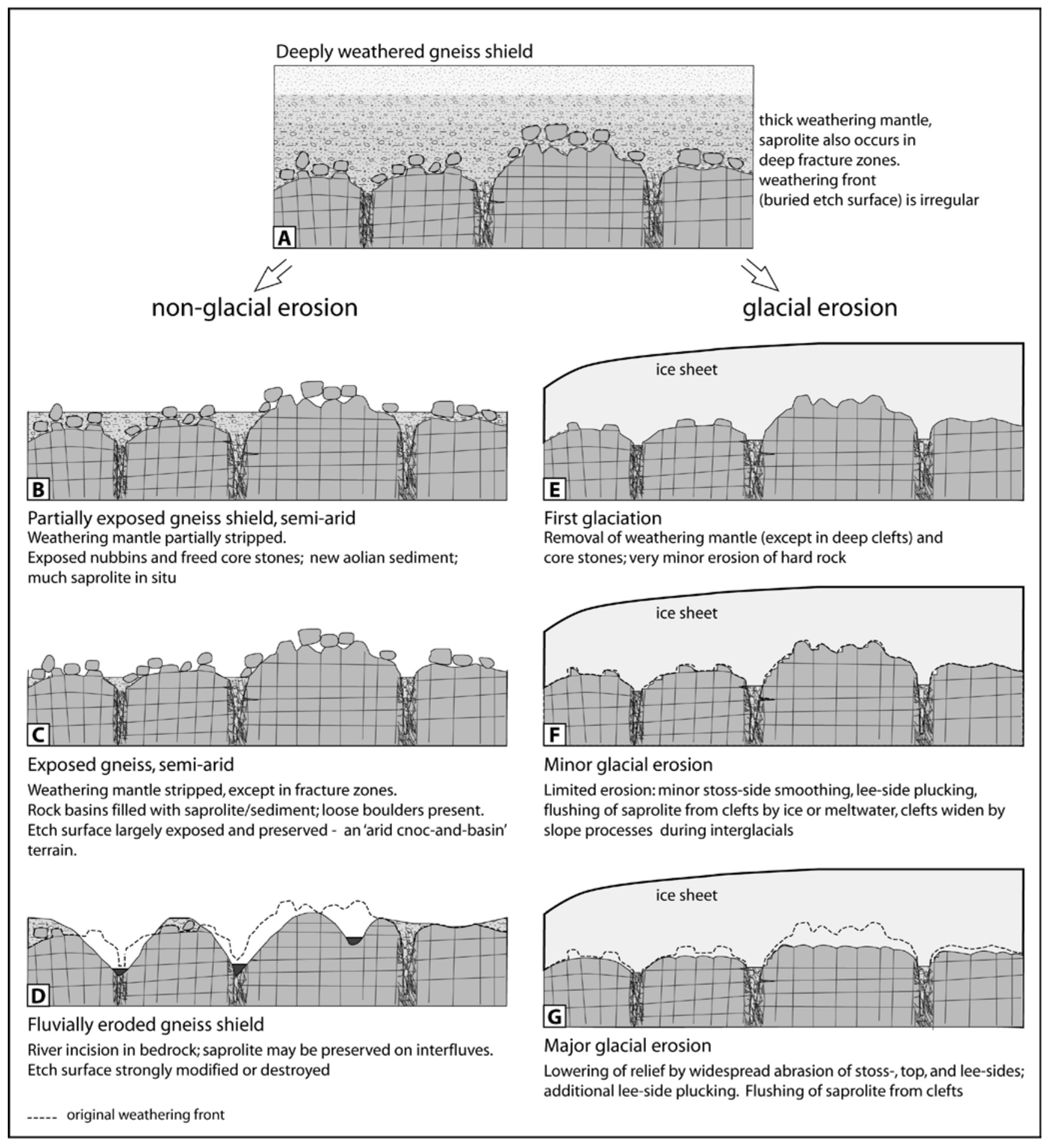

Fig. 11. Schematic diagram, illustrating the evolution of deeply weathered gneiss terrains under different climatic conditions, for further discussion see text.

(A) Deeply weathered gneiss shield in tectonically stable situation

(B) Gneiss partially exposed under semi-arid conditions

(C) Gneiss completely exposed under semi-arid conditions (e.g. Namaqualand)

(D) Fluvial erosion, incision

(E) Glacial erosion: after first glaciation

(F) Further minor glacial erosion

(G) Further major glacial erosion, by sustained, fast ice flow, e.g. ice streaming 
A study in the Sudetes region (central Europe), only covered once by glaciation, gives an idea of such 'first glaciation' erosion in a granite-dominated terrain (Hall and Migoń, 2010). In North America, removal or 'stripping' of pre-Quaternary saprolite from the Canadian Shield by the earliest Plio-Pleistocene Laurentide Ice Sheet is supported by till composition analyses showing that early Pleistocene tills are enriched in minerals derived from saprolite, whilst late Pleistocene tills are enriched in minerals derived from fresh, unweathered rock (Clark and Pollard, 1998; Roy et al., 2004a, b).

The key issue now centres on the degree of glacial erosion of the fresh, hard bedrock surface by subsequent glaciations, once the saprolite is removed (Fig. 11F versus Fig 11G). Bradwell (2013) showed that within the Lewisian gneiss landscape of NW Scotland there are significant variations in landforms, caused by variations in glacial erosion style and palaeo-ice velocity. A distinction may thus be made between areas of exposed gneiss subjected to varying degrees of glacial modification.

\subsection{Minor glacial modification of hard bedrock gneiss}

The following features, observed over much of the cnoc-and-lochan terrain in NW Scotland, suggest a modest degree of glacial modification of the exposed gneiss bedrock (Fig. 11F):

1) Many rock knolls are asymmetric, with smooth stoss-side and steep, plucked lee-sides. Such roches moutonnées are here interpreted as glacially modified highs ('nubbins', 'tors', castle koppies' - Twidale, 1982) of the exhumed weathering front (see also Lindström, 1988);

2) Many linear valleys at high angles to palaeo-ice flow are also asymmetric, with smoother down-ice sides and steep up-ice sides. This asymmetry is interpreted to be caused by a combination of abrasion and plucking, analogous to roche moutonnées (e.g. Glasser and Warren, 1990). Widening of the linear valleys is mainly achieved by plucking.

3) Linear valleys subparallel to palaeo-ice flow have steep faces marked by small post-glacial rock falls. These linear valleys are probably formed by a combination of subglacial abrasion and lateral plucking (see Krabbendam and Bradwell, 2011 for an explanation of lateral plucking) and a repeated sequence of slope collapse and rock falls during interglacials and clearing out of debris during glacial erosion, similar to glacial valley widening (e.g. McColl, 2012) but on a smaller scale. These linear valleys may also have functioned as (subglacial) meltwater channels, so a component of pro-glacial and subglacial fluvial erosion is possible.

Nevertheless, it is likely that the overall amount of erosion of hard, fresh bedrock was minor, because of the following reasons:

a) Areas of moderate glacial modification are characterised by high roughness (Fig. 4A). The similarity with terrain features in Namaqualand suggests that much of the surface corresponds to the old weathering front.

b) The scarcity of till cover, suggesting limited generation of basal debris;

c) Weathering remnants are still preserved. 


\subsection{Major glacial modification:}

In the Laxford area, glacial landforms such as P-forms and wholly abraded bedforms (whalebacks) are more abundant than in adjacent areas (Bradwell, 2013). Overall, the landscape is much smoother and more streamlined (Fig. 4B; 11G). On bedrock hills and adjacent valleys, all sides are smoothed by abrasion (Fig. 7A); plucked faces are rare. This landform assemblage is similar to that described from deglaciated parts in West Greenland in the former path of the fast-flowing Jakobshavn Isbrae (Roberts and Long, 2005). Bradwell (2013) interpreted this highly streamlined zone as being eroded beneath a (tributary of) a palaeo-ice stream, that was topographically controlled in its upper reaches between the mountains of Arkle and Ben Stack (Fig. 3). Major glacial modification thus led to a smoothing of an originally rougher landscape.

On a vertical image, the network of linear valleys is equally visible in the Laxford zone as elsewhere (compare Fig. 5A and 5B). This shows that the whilst the stronger glacial erosion in the Laxford Zone led mainly to a smoothing, rounding and lowering of pre-existing hills, it did not affect the spacing of the linear valleys . Thus, we suggest that the strong glacial erosion in the Laxford corridor has lowered the amplitude (vertical component) of roughness, but not its wavelength (horizontal component), which is essentially predetermined by the spacing of the pre-existing fracture zones (Fig. 11E-G). This implies that any variation of glacial modification or erosion is difficult to determine from 2D map view or satellite imagery alone, but can only be determined by detailed fieldwork (eg. Bradwell, 2013), or possibly by analysis of high resolution (e.g. LiDAR) digital terrain models ( $\leq 1 \mathrm{~m}$ resolution). Another implication is that the concept of lake density as a proxy for glacial erosion intensity is not generally applicable (cf. Sugden, 1978; Briner et al., 2008).

\subsection{Why Gneiss? Lithological control on landscape development}

Why does the cnoc-and-lochan landscape develop typically on gneiss and granitic rocks and not on other rocks? The answer lies in a number of physical and chemical bedrock properties that are most widespread in gneiss terrains.

1) Firstly, gneisses and related granitic rocks are rich in minerals such as plagioclase, biotite and hornblende that readily break down by chemical weathering under moist atmospheric conditions (e.g. Goldich, 1938, Nesbitt and Markovics, 1997). As a consequence such rocks are prone to develop thick weathering mantles. In contrast, many sedimentary rocks (e.g. quartzite, shale) are composed of minerals that are chemically more stable under atmospheric conditions, and thus weather more slowly.

2) Secondly, sedimentary rocks are usually strongly layered, with bedding planes representing pronounced and highly anisotropic rock weaknesses. Consequently, long term weathering and erosion of sedimentary rocks therefore tend to develop cuesta-type landscapes. Cuesta-type landscapes can be modified by glacial erosion, but the resultant 'hard-bed landform assemblage' has a very different geomorphology, commonly characterized by bedrock megagrooves (e.g. Zumberge, 1954; Krabbendam and Bradwell, 2011; Eyles, 2012). 
3) Thirdly, flat-lying gneiss terrains are typically old (>500 Ma) and thus have had time to develop a relatively dense, mature network of fractures. As a consequence, granitic rocks in ancient gneiss terrains behave similarly to gneiss (e.g. Johansson et al., 2001b; Olvmo and Johansson, 2002), whilst granites in younger mountain belts commonly have a much wider joint spacing. A good example of this is the Sierra Nevada batholith in California (intruded between 95-85 Ma; Memeti et al., 2010), where Yosemite granite typically has a very wide joint spacing (Mathes, 1930; Dühnforth et al., 2010).

4) Finally, the contrast in intact rock strength between fresh gneiss and its saprolite is very high - much higher than for most other rocks (Fig. 12). Thus the weathering front in a gneiss terrain represents a much stronger mechanical contrast than in most other rocks: fresh gneiss is highly resistant to glacial erosion whilst its saprolite is highly prone to erosion. Furthermore, most fresh sedimentary rocks are more prone to glacial erosion than fresh gneiss because of their lower intact rock strength.

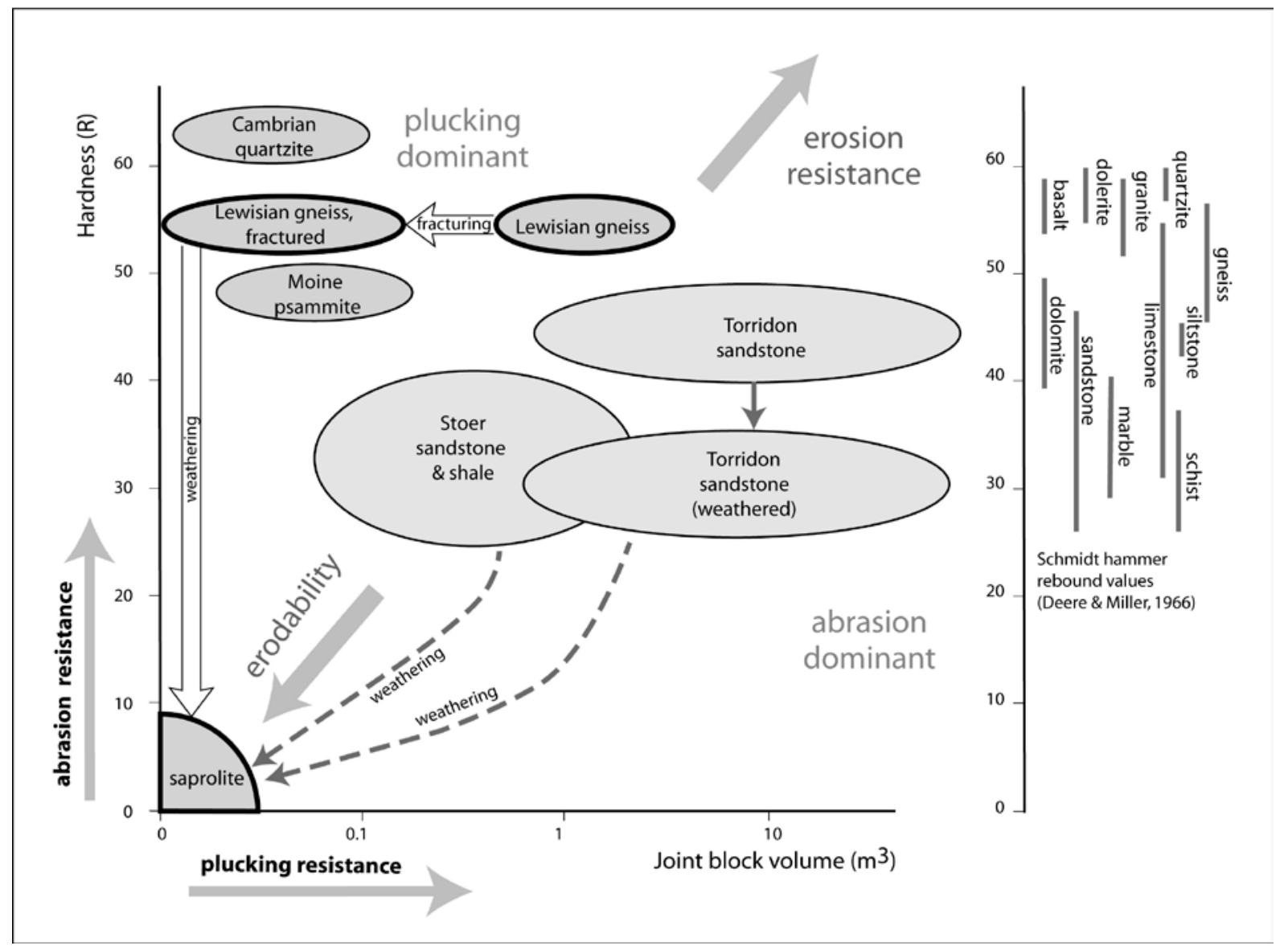

Fig. 12. Bedrock properties (hardness and joint block volume) of gneiss and some other rocks (with data after Krabbendam and Glasser, 2011) compared to saprolite, see text for further discussion

It thus appears that any massive rock with a mature fracture network, susceptible to weathering and subjected to long-term weathering could in theory develop a 'cnoc-and-lochan' type landscape under the appropriate climatic conditions (both glacial and semi-arid). It just happens that gneisses and associated igneous intrusions are the most widely occurring rocks on Earth with such attributes. 


\subsection{Implications for sub-glacial bed roughness under modern ice sheets}

The widespread occurrence of ‘cnoc-and-lochan' type topography on deglaciated gneiss terrains in Scotland, Canada, and Scandinavia suggests that similar surfaces may form the bed of parts of present-day ice sheets where composed of gneiss. Gneiss underlies much of the Greenland Ice Sheet (Henriksen et al., 2000) and Holocene deglaciation of gneiss terrains in West Greenland indeed has revealed a similar cnoc-and-lochan terrain (Roberts and Long, 2005). This inference may be used to better constrain dynamic models of ice sheets, which currently do not use quantified small-scale roughness parameters (e.g. Parizek and Alley, 2004).

However, there are significant variations in the roughness of different gneiss terrains, because of differences in either the pre-glacial or the glacial evolution of the landscape, and a better understanding of the causes of these variations in roughness is needed.

In terms of the pre-glacial history, the roughness of the etch surface prior to glaciation can vary significantly. As an example, in southern Sweden, the etch surface exhumed from beneath Cambrian sedimentary rocks in relative recent times is remarkably smooth with few saprolite remains. In contrast, the etch surface that has appeared from beneath Cretaceous cover sediments has a relative relief of up to $50 \mathrm{~m}$, with locally thick saprolite remnants (Johansson, 1999; Lidmar-Bergström, 1989; 1995). The depth of a weathering mantle and the roughness of the weathering front prior to Pleistocene glaciation depends on a range of factors including lithology, fracture zone density, climate, vegetation, atmospheric chemistry, time of exposure and whether or not a weathering mantle was removed previously and/or covered by other rocks (Kroonenberg and Melitz, 1983; Lidmar-Bergström, 1995; Ollier, 1984; Twidale, 2002). Little is known or understood about weathering processes during the Precambrian but it appears that the mechanisms of producing and retaining Precambrian weathering mantles was very different from Phanerozoic weathering due to lack of terrestrial vegetation and other factors (e.g. Berner, 1992; Elvhage and Lidmar-Bergström, 1987; Russel and Allison 1985; Retallack and Mindszenty, 1994)

In terms of glacial evolution three cases can be distinguished: minimal, moderate and intense glacial modification.

In certain locations it is possible that glacial modification is so minimal that stripping of the weathering mantle is incomplete and the weathering front (etch surface) has not been exposed. This appears to be the case in parts of northern Sweden, where weathering landforms such as tors and gently sloping inselbergs or monadnocks and saprolite remnants are abundant; few rock basins occur. Thin till veneers, presumably sourced from nearby in-situ weathered material, contribute to the smooth terrain (Hall et al., 2012; Hättestrand and Stroeven 2002; Stroeven et al. 2002). Similarly, areas showing relict pre-glacial landscape features such as tors and blockfields (felsenmeer) in the high Arctic of Canada also suggest very limited glacial erosion (Bird, 1959; Dyke, 1993; Kleman and Hättestrand, 1999; Sugden and Watts, 1977; Watts, 1983). In both cases the (partial) survival of a pre-glacial landscape is attributed to long-term cover by predominantly cold ice, resulting in very low glacial erosion rates (e.g. Hättestrand and Stroeven 2002; 
Kleman and Hättestrand, 1999; Sugden and Watts, 1977). Strictly speaking, such landscapes are not cnocand-lochan landscapes in that they are not bedrock-dominated and lack both the 'cnocs' and the' lochans'. In other words, the lack of development of a cnoc-and-lochan topography on a glaciated gneiss terrain may occur if long-term protection by cold-based ice-sheet conditions resulted in minimal glacial erosion.

The cases for moderate and intense glacial modification have been outlined above. Overall it appears that the roughest gneiss topography would be expected in terrains that experienced long-term deep weathering during the Phanerozoic, and in which subsequent Pleistocene glacial erosion was sufficient to remove the weathering mantle, but not so intense as to reduce the relative relief by significant (hard) bedrock erosion beneath sustained, fast ice-sheet flow corridors.

\section{CONCLUSIONS}

From the analysis of landforms and bedrock structures in NW Scotland gneiss terrain and the comparison with a non-glaciated gneiss terrain in Namaqualand, the following conclusions are drawn.

- Glaciated gneiss terrains exhibit a complex 'hard-bed landform assemblage', comprising a number of distinct and composite landforms on a range of different spatial scales.

- Most large/medium-scale landforms are influenced by the bedrock structure of the gneisses, in particular fracture zones.

- Many large/medium-scale landforms also occur in non-glacial settings; they are in essence preglacial in origin and broadly conform to the 3D shape of the weathering front resulting from long periods of pre-glacial weathering (e.g. large residual hills, basins, linear valleys and star-shaped basins). In glaciated areas, glaciation effectively removed the saprolite. The overall roughness of the cnoc-and-lochan terrain is therefore primarily the result of inheritance from an irregular, preglacial weathering front.

- Some bedrock landforms, such as large overdeepened linear basins, are predominantly formed by glacial erosion although these may still follow pre-existing, deeply weathered zones coinciding with fracture zones.

- Many landforms are the result of glacial modification (over several glacial/interglacial cycles) of pre-glacial landforms or linear zones of weak material. Mechanisms include widening of linear valleys, streamlining of whalebacks and plucking to form roches moutonnées;

- The degree of glacial modification of pre-existing bedrock landforms varies from place to place, depending on glacial thermal regime and ice velocity integrated over several glacial cycles, with more intense glacial modification beneath hard-bed palaeo-ice streams.

Glaciated, bedrock-dominated gneiss landscapes result from a multistage landscape evolution involving:

1) Long-term weathering, creating a thick weathering mantle with a deep, irregular weathering front largely controlled by fracture zones;

2) Stripping of the weathering mantle during the first glaciation(s) by subglacial and possibly glaciofluvial erosion. Once the saprolite mantle is removed, gneiss terrains become highly resistant to 
glacial erosion, due to the high rock strength of unweathered gneiss compared to its saprolite. These first two steps create in a rough surface, which broadly conforms to the pre-existing, rough weathering front. 3) Glacial modification by warm-based subglacial erosion (abrasion and plucking) of the now exposed weathering front. This results in the modification of existing features, producing asymmetry and streamlining by directed ice flow. Minor glacial modification does leave a rough landscape, with limited erosion of hard bedrock. More intense deep glacial erosion of hard bedrock only occurs in areas of sustained fast ice flow. We suggest that only this process leads to a streamlined glacial landscape, which is smoother than the less-glacially modified landscape.

Glaciated gneiss terrains subjected to warm-based ice are inherently rough, albeit variably so.

Knowledge of this roughness can potentially be applied to constrain bed roughness below present-day ice sheets where gneiss is known to form its bed, as is largely the case for much of the Greenland Ice Sheet.

\section{Acknowledgements}

Andrew Finlayson and Adrian Hall are thanked for discussions on weathering and erosion. Karna Lidmar-Bergström and Niko Putkinen are thanked for helpful and insightful reviews. Kay Smith is thanked for assistance with processing satellite imagery. The authors publish with permission of the Director of the British Geological Survey (Natural Environmental Research Council). 


\section{References}

Alley, R.B., 1991. Deforming-bed origin for southern Laurentide till sheets? Journal of Glaciology 37, 67-76.

Anand, R.R., Paine, M., 2002. Regolith geology of the Yilgarn Craton, Western Australia: implications for exploration. Australian Journal of Earth Sciences 49, 3-162.

Attfield, P., 1987. The structural history of the Canisp Shear Zone. Geological Society, London, Special Publications 27, 165-173.

Aydin, A., Basu, A., 2005. The Schmidt hammer in rock material characterization. Engineering Geology 81, 1-14.

Ballantyne, C., Stone, J., 2011. Did large ice caps persist on low ground in north-west Scotland during the Lateglacial Interstade? Journal of Quaternary Science 27, 297-306.

Ballantyne, C.K., 1995. Periglacial features of Assynt and Coigach, In: Lawson, T.J. (Ed.), The Quaternary of Assynt and Coigach; field guide., Quaternary Research Association, pp. 47-60.

Bárdossy, G., Aleva , G.J.J., 1990. Lateritic bauxites. Elsevier, Amsterdam.

Beacom, L.E., Holdsworth, R.E., McCaffrey, K.J.W., Anderson, T.B., 2001. A quantiative study of the influence of preexisting compositional and fabric heterogeneities upon fracture-zone development during basement reactivation. Geological Society, London, Special Publications 186, 195-211.

Bell, M., Laine, E.P., 1985. Erosion of the Laurentide region of North America by glacial and glaciofluvial processes. Quaternary Research 23, 154-174.

Benn, D.I., Evans, D.J.A., 2011. Glaciers and glaciation, 2nd Edition. Hodder Arnold Education, London.

Benn, D.I., Lukas, S., 2006. Younger Dryas glacial landsystems in North West Scotland: an assessment of modern analogues and palaeoclimatic implications. Quaternary Science Reviews 25, 2390-2408.

Berner, R.A., 1992. Weathering, plants, and the long-term carbon cycle. Geochimica et Cosmochimica Acta 56, 32253231.

Bingham, R.G., Siegert, M.J., 2009. Quantifying subglacial bed roughness in Antarctica: implications for ice-sheet dynamics and history. Quaternary Science Reviews 28, 223-236.

Bird, J.B., 1959. Recent contributions to the physiography of Northern Canada. Zeitschrift fuer Geomorphologie 3, 151174.

Boger, S.D., 2011. Antarctica — Before and after Gondwana. Gondwana Research 19, 335-371.

Bonow, J., 2005. Re-exposed basement landforms in the Disko region, West Greenland—disregarded data for estimation of glacial erosion and uplift modelling. Geomorphology 72, 106-127.

Bouchard, M., Jolicoeur, S., Pierre, G., 1995. Characteristics and significance of two pre-late-Wisconsinan weathering profiles (Adirondacks, USA and Miramichi Highlands, Canada). Geomorphology 12, 75-89.

Boulton, G.S., Hindmarsh, R.C.A., 1987. Sediment deformation beneath glaciers: Rheology and geological consequences. Journal of Geophysical Research 92 (B9), 9059-9082.

Bradwell, T., 2006. The Loch Lomond Stadial Glaciation in Assynt: a reappraisal. Scottish Geographical Journal 122, 274-292.

Bradwell, T., 2013. Identifying palaeo-ice streams on hard beds: mapping glacial bedforms and erosional zones in NW Scotland. Geomorphology 201, 397-414.

Bradwell, T., Stoker, M., Larter, R., 2007. Geomorphological signature and flow dynamics of The Minch palaeo-ice stream, northwest Scotland. Journal of Quaternary Science 22, 609-617.

Bradwell, T., Stoker, M.S., Krabbendam., M., 2008a. Megagrooves and streamlined bedrock in NW Scotland: the role of ice streams in landscape evolution. Geomorphology 97, 135-156 
Bradwell, T.B., Stoker, M.S., Golledge, N.R., Wilson, C.K., Merritt, J.W., Long, D., Everest, J.D., Hestvik, O.B., Stevenson, A.G., Hubbard, A.L., Finlayson, A.G., Mathers, H.E., 2008b. The northern sector of the last British Ice Sheet: Maximum extent and demise. Earth Science Reviews 88, 207-226.

Brandt, D., Andreoli, M.A.G., McCarthy, T.S., 2003. Mesozoic fluvial deposits on a rifted continental margin near Vaalputs, Namaqualand, South Africa. South African Journal of Geology 106, 11-16.

Brandt, D., Andreoli, M.A.G., McCarthy, T.S., 2005. The late Mesozoic palaeosoils and Cenozoic fluvial deposits at Vaalputs, Namaqualand, South Africa: possible depositional mechanisms and their bearing on the evolution of the continental margin. South African Journal of Geology 108, 271-284.

Briner, J.P., Miller, G.H., Finkel, R., Hess, D.P., 2008. Glacial erosion at the fjord onset zone and implications for the organization of ice flow on Baffin Island, Arctic Canada. Geomorphology 97, 126-134.

British Geological Survey, 2007a. Bedrock Geology UK North, 1:625 000 scale. British Geological Survey, Keyworth, Nottingham.

British Geological Survey, 2007b. Assynt. Scotland Special Sheet, Bedrock. 1:50 000 Geology Series. British Geological Survey, Keyworth, Nottingham.

British Geological Survey, 2013. Ullapool, Scotland Sheet 101E, Superficial Deposits, 1:50 000 Series. British Geological Survey, Keyworth, Nottingham.

Clark, P.U., Pollard, D., 1998. Origin of the middle Pleistocene transition by ice sheet erosion of regolith. Paleoceanography 13, 1-9.

Cliff, R.A., Rex, D., Guise, P.G., 1998. Geochronological studies of Proterozoic crustal evolution in the northern Outer Hebrides. Precambrian Research 91, 401-418.

Davis, G.H., Reynolds, S.J., 1996. Structural geology of rocks and regions, 2nd edition. John Wiley, New York. De Wit, M.C.J., 1999. Post-Gondwana drainage and the development of diamond placers in western South Africa. Economic Geology 94, 721-740.

Deere, D.U., Miller, R.P., 1966. Engineering classification and index properties for intact rock, Air Force Weapons Laboratory Technical Report. AFWL-TR-65-116

Dühnforth, M., Anderson, R.S., Ward, D., Stock, G., 2010. Bedrock fracture control of glacial erosion processes and rates. Geology 38, 423 - 426.

Dyke, A.S., 1993. Landscapes of cold-centred Late Wisconsinan ice caps, Arctic Canada. Progress in Physical Geography 17, 223-247.

Ehlers, J., Gibbard, P., 2004. Quaternary glaciations: extent and chronology. Part 2: North America, Developments in Quaternary Science. Elsevier, Amsterdam.

Ellis, M.A., Laubach, S.E., Eichhubl, P., Olson, J.E., hargrove, P., 2012. Fracture development and diagenesis of Torridon Group Applecross Formation, near An Teallach, NW Scotland: millennia of brittle deformation resilience? Journal of the Geological Society of London 169, 297-310.

Elvhage, C., Lidmar-Bergström, K., 1987. Some working hypotheses on the geomorphology of Sweden in the light of a new relief map. Geografiska Annaler 69A, 343 - 358.

Eyles, N., 2012. Rock drumlins and megaflutes of the Niagara Escarpment, Ontario, Canada: a hard bed landform assemblage cut by the Saginaw-Huron Ice Stream. Quaternary Science Reviews, 55, 34-49.

Fabel, D., Ballantyne, C.K., Xu, S., 2012. Trimlines, blockfields, mountain-top erratics and the vertical dimensions of the last British-Irish Ice Sheet in NW Scotland. Quaternary Science Reviews 55, 91-102.

Fairbridge, R.W., Finkl, C.W., 1980. Cratonic erosional unconformities and peneplains. Journal of Geology 88, 69-86. 
Finlayson, A., Bradwell, T., 2008. Morphological characteristics, formation and glaciological significance of Rogen moraine in northern Scotland. Geomorphology 101, 607-617.

Fretwell, P., Pritchard, H.D., Vaughan, D.G., Bamber, J.L., Barrand, N.E., Bell, R., Bianchi, C., Bingham, R.G., Blankenship, D.D., Casassa, G., Catania, G., Callens, D., Conway, H., Cook, A.J., Corr, H.F.J., Damaske, D., Damm, V., Ferraccioli, F., Forsberg, R., Fujita, S., Gogineni, P., Griggs, J.A., Hindmarsh, R.C.A., Holmlund, P., Holt, J.W., Jacobel, R.W., Jenkins, A., Jokat, W., Jordan, T., King, E.C., Kohler, J., Krabill, W., Riger-Kusk, M., Langley, K.A., Leitchenkov, G., Leuschen, C., Luyendyk, B.P., Matsuoka, K., Nogi, Y., Nost, O.A., Popov, S.V., Rignot, E., Rippin, D.M., Riviera, A., Roberts, J., Ross, N., Siegert, M.J., Smith, A.M., Steinhage, D., Studinger, M., Sun, B., Tinto, B.K., Welch, B.C., Young, D.A., Xiangbin, C., Zirizzotti, A., 2012. Bedmap2: improved ice bed, surface and thickness datasets for Antarctica. The Cryosphere 6, 4305-4361.

Fyfe, J.A., Long, D., Evans, D., 1993. The geology of the Malin-Hebrides sea area, United Kingdom offshore regional report. HMSO for British Geological Survey, London.

Gagliardini, O., Cohen, D., Råback, P., Zwinger, T., 2007. Finite-element modeling of subglacial cavities and related friction law. Journal of Geophysical Research: Earth Surface 112, F02027.

Gilchrist, A.R., Kooi, H., Beaumont, C., 1994. Post-Gondwana geomorphic evolution of southwestern Africa: Implications for the controls on landscape development from observations and numerical experiments. Journal of Geophysical Research B6, 12211-12228.

Glasser, N.F., Warren, C.R., 1990. Medium scale landforms of glacial erosion in South Greenland; process and form. Geografiska Annaler 72A, 211-215.

Godard, A., 1957. La surface prétorridonienne en Ecosse. Revue de Géographie Alpine 45, 135-153.

Goldich, S.S., 1938. A study in rock-weathering. Journal of Geology 46, 17-58.

Goodenough, K.M., Park, R.G., Krabbendam, M., Myers, J.S., Wheeler, J., Loughlin, S.C., Crowley, Q.G., L, F.C.R., Beach, A., Kinny, P.D., Graham, R.H., 2010. The Laxford Front: an end-Archaean terrane boundary? Geological Society, London, Special Publications 335, 101-118.

Goodwin, A., 1996. Principles of Precambrian Geology. Academic Press.

Gordon, J.E., 1981. Ice-scoured topography and its relationship to bedrock structure and ice movements in parts of Northern Scotland and west Greenland. Geografiska Annaler 63A, 55-65.

Hall, A.M., 1985. Cenozoic weathering covers in Buchan, Scotland and their significance. Nature 315, 392-395.

Hall, A.M., 1991. Pre-Quaternary landscape evolution in the Scottish Highlands. Transactions of the Royal Society of Edinburgh: Earth Sciences 8, 1-26.

Hall, A.M., Ebert, K., Hättestrand, C., 2012. Pre-glacial landform inheritance in a glaciated shield landscape. Geografiska Annaler 95A, 33-49.

Hall, A.M., Mellor, A., 1988. The characteristics and significance of deep weathering in the Gaick area, Grampian Highlands, Scotland. Geografiska Annaler 70A, 309-314.

Hall, A.M., Migoń, P., 2010. The first stages of erosion by ice sheets: Evidence from central Europe. Geomorphology 123, 349-363.

Hättestrand, C., Stroeven, A.P., 2002. A relict landscape in the centre of Fennoscandian glaciation: Geomorphological evidence of minimal Quaternary glacial erosion. Geomorphology 44, 127-143.

Heaman, L., Tarney, J., 1989. U-Pb baddeleyite ages for the Scourie dyke swarm, Scotland: evidence for two distinct intrusion events. Nature 340, 705-708. 
Henriksen, N., Higgins, A.K., Kalsbeek, D., Pulvertaft, T.C.R., 2000. Greenland from Archaean to Quaternary. Descriptive text to the Geological map of Greenland, 1:2 500 000, Geology of Greenland Survey. GEUS, Copenhagen.

Holford, S.P., Green, P.F., Hillis, R.R., Underhill, J.R., Stoker, M.S., Duddy, I.R., 2010. Multiple post-Caledonian exhumation episodes across NW Scotland revealed by apatite fission-track analysis. Journal of the Geological Society 167, 675-694.

Hooyer, T., Cohen , D., Iverson, N., 2012. Control of glacial quarrying by bedrock joints. Geomorphology 153-154, 91101.

Hubbard, A., Bradwell, T., Golledge, N., Hall, A., Henry Patton, H., David Sugden, D., Cooper, R., Martyn Stoker, M., 2009. Dynamic cycles, ice streams and their impact on the extent, chronology and deglaciation of the BritishIrish ice sheet. Quaternary Science Reviews 28, 759-777.

Hubbard, B., Siegert, M.J., McCarroll, D., 2000. Spectral roughness of glaciated bedrock geomorphic surfaces: Implications for glacier sliding. Journal of Geophysical Research 105, 21295-21203.

Irfan, T.Y., Powell, G.E., 1985. Engineering geological investigations for pile foundations on a deeply weathered granitic rock in Hong Kong. Bulletin of the International Association of Engineering Geology 32, 67-80.

Jackson, M.P.A., 1979. A major charnockite-granolite province in southwestern Africa. Geology 7, 22-26.

Johansson, M., 1999. Analysis of digital elevation data for palaeosurfaces in south-western Sweden. Geomorphology 26, 279-295.

Johansson, M., Migon, P., Olvmo, M., 2001b. Development of joint-controlled rock basins in Bohus granite, SW Sweden. Geomorphology 40, 145-161.

Johansson, M., Olvmo, M., Lidmar, B.K., 2001a. Inherited landforms and glacial impact of different palaeosurfaces in Southwest Sweden. Geografiska Annaler 83A, 67-89.

Kleman, J., Hättestrand, C., 1999. Frozen-bed Fennoscandian and Laurentide ice sheets during the Last Glacial Maximum. Nature 402, 63-66.

Kounov, A., Viola, G., De Wit, M., Andreoli, M., 2009. Denudation along the Atlantic passive margin: new insights from apatite fission-track analysis on the western coast of South Africa. Geological Society, London, Special Publications 324, 287-306.

Krabbendam, M., Bradwell, T., 2010. The geology and landscape of the Northwest Highlands: an introduction, In: Lukas, S., Bradwell, T. (Eds.), The Quaternary of Western Sutherland and adjacent areas: Field Guide. Quaternary Research Association, London, pp. 3-12.

Krabbendam, M., Bradwell, T., 2011. Lateral plucking as a mechanism for elongate erosional glacial bedforms: explaining megagrooves in Britain and Canada. Earth Surface Processes and Landforms 36, 1335-1349.

Krabbendam, M., Glasser, N.F., 2011. Glacial erosion and bedrock properties in NW Scotland: Abrasion and plucking, hardness and joint spacing. Geomorphology 130, 374-383.

Krabbendam, M., Leslie, A.G., 2010. Lateral variations and linkages in thrust geometry: the Traligill Transverse Zone, Assynt Culmination, Moine Thrust Belt, NW Scotland. Geological Society. London, Special Publications 335, 333-356.

Kroonenberg, S.B., Melitz, P.J., 1983. Summit levels, bedrock control and the etchplain concept in the basement of Suriname. Geologie en Mijnbouw 62, 389-399.

Lawson, T.J., 1986. Loch Lomond Advance glaciers in Assynt, Sutherland, and their palaeoclimatic implications. Scottish Journal of Geology 22, 289-298. 
Lawson, T.J., 1990. Former ice movement in Assynt, Sutherland, as shown by the distribution of glacial erratics. Scottish Journal of Geology 26, 25-32.

Lawson, T.J., 1995. Glacial landforms, In: Lawson, T.J. (Ed.), The Quaternary of Assynt and Coigach; field guide. , Quaternary Research Association, pp. 35-46.

Lawson, T.J., 1996. Glacial striae and former ice movement; the evidence from Assynt, Sutherland. Scottish Journal of Geology 32, 59-65.

Lee, J.R., Busschers, F.S., Sejrup, H.P., 2012. Pre-Weichselian Quaternary glaciations of the British Isles, The Netherlands, Norway and adjacent marine areas south of $68^{\circ} \mathrm{N}$ : implications for long-term ice sheet development in northern Europe. Quaternary Science Reviews 44, 213-228.

Lidmar-Bergström, K., 1988. Denudation surfaces of a shield area in south Sweden. Geografiska Annaler 70A, 337350.

Lidmar-Bergström, K., 1989. Exhumed Cretaceous landforms in south Sweden. Zeitschrift für Geomorphologie, Neue Folge 72, 21-40.

Lidmar-Bergström, K., 1995. Relief and saprolites through time on the Baltic Shield. Geomorphology 12, 45-61.

Lidmar-Bergström, K., 1997. A long-term perspective on glacial erosion. Earth Surface Processes and Landforms 22, 297-306.

Lidmar-Bergström, K., Näslund, J.O., 2002. Landforms and uplift in Scandinavia. Geological Society. London, Special Publications 196, 103-116.

Lidmar-Bergström, K., Olsson, S., Olvmo, M., 1997. Palaeosurfaces and associated saprolites in southern Sweden. Geological Society. London, Special Publications 120, 95-124.

Lindström, E., 1988. Are roches moutonnées mainly preglacial forms? Geografiska Annaler 70A, 323-331.

Linton, D.L., 1963. The forms of glacial erosion. Transactions of the Institute of British Geographers 33, 1-28.

Luft, F.F., Luft Jr, J.L., Chemale Jr, F., Lelarge, M.L.M.V., Ávila, J.N., 2005. Post-Gondwana break-up record constraints from apatite fission track thermochronology in NW Namibia. Radiation Measurements 39, 675-679.

Mathes, F.E., 1930. Geologic history of the Yosemite Valley., USGS Professional Paper. US Geological Survey. 160

McCarthy, T.S., Moon, B.P., Levin, M., 1985. Geomorphology of the Western Bushmanland Plateau, Namaqualand, South Africa. South African Geographical Journal 67, 160-178.

McColl , S.T., 2012. Paraglacial rock-slope stability. Geomorphology 153-154, 1-16.

Migoń, P., 2006. Granite landscapes of the world. Oxford University Press, Oxford.

Migoń, P., Lidmar-Bergström, K., 2001. Weathering mantles and their significance for geomorphological evolution of central and northern Europe since the Mesozoic. Earth Science Reviews 56, 285-324.

Miller, K.G., Kominz, M.A., Browning, J.V., Wright, J.D., Mountain, G.S., Katz, M.E., Sugarman, P.J., Cramer, B.S., Christie-Blick, N., Pekar, S.F., 2005. The Phanerozoic record of global sea-level change. Science 310, 12931298.

Morton, N., 1992. Dynamic stratigraphy of the Triassic and Jurassic of the Hebrides Basin, NW Scotland. Geological Society. London, Special Publications 62, 97-110.

Nesbitt, H., W , Markovics , G., 1997. Weathering of granodioritic crust, long-term storage of elements in weathering profiles, and petrogenesis of siliciclastic sediments. Geochimica et Cosmochimica Acta 61, 1653-1670.

Ollier, C., 1984. Weathering, 2nd Edition, Geomorphology texts. Longman, London.

Olvmo, M., Johansson, M., 2002. The significance of rock structure, lithology and pre-glacial deep weathering for the shape of intermediate-scale glacial erosional landforms. Earth Surface Processes and Landforms 27, 251-268. 
Olvmo, M., Lidmar-Bergstrom, K., Ericson, K., Bonow, J., 2005. Saprolite remnants as indicators of pre-glacial landform genesis in Southeast Sweden. Geografiska Annaler 87A, 447-460.

Olvmo, M., Lidmar-Bergström, K., Lindberg, G., 1999. The glacial impact on an exhumed sub-Mesozoic etch surface in south-western Sweden. Annals of Glaciology 28, 153-160.

Parizek, B.R., Alley, R.B., 2004. Implications of increased Greenland surface melt under global-warming scenarios: ice-sheet simulations. Quaternary Science Reviews 23, 1013-1027.

Park, R.G., 2005. The Lewisian terrane model: a review. Scottish Journal of Geology 41, 105-118.

Patterson, W.S.B., 1994. The physics of glaciers, 3rd edition. Pergamon, Oxford.

Peach, B.N., Horne, J., Gunn, W., Clough, C.T., Hinxman, L.W., Teall, J.J.H., 1907. The geological structure of the North-West Highlands of Scotland, Memoir of the Geological Survey of Great Britain. HMSO.

Petra, N., Zhu, H., Stadler, G., Hughes, T.R., Ghattas, O., 2012. An inexact Gauss-Newton method for inversion of basal sliding and rheology parameters in a nonlinear Stokes ice sheet model. Journal of Glaciology 58, 889-903.

Phillips, E., Everest, J., Diaz-Doce, D., 2010. Bedrock controls on subglacial landform distribution and geomorphological processes: Evidence from the Late Devensian Irish Sea Ice Stream. Sedimentary Geology 232, 98-118.

Pless, J.C., 2011. Characterising fracture basement using the Lewisian Gneiss Complex, NW Scotland: Implications for fracture systems in the Clair Field basement. Durham University, p. 606.

Rastas, J., Seppälä, M., 1981. Rock jointing and abrasion forms on roches moutonnées, SW Finland. Annals of Glaciology 2, 159-163.

Rea, B.R., 1994. Joint control in the formation of rock steps in the subglacial environment, In: Robinson, D.A., Williams, R.B.G. (Eds.), Rock weathering and landform evolution. , John Wiley, pp. 473-486.

Rea, B.R., Evans, D.J.A., 1996. Landscapes of aerial scouring in NW Scotland. Scottish Geographical Magazine 112 47-50.

Read, H.H., Phemister, J., Ross, G., Dinham, C.H., Macgegor, M., 1926. The geology of Strath Oykell and Lower Loch Shin (South Sutherlandshire and north Ross-shire) (Explanation of sheet 102), Memoir of the Geological Survey of Great Britain. HMSO, Edinburgh.

Retallack, G.J., Mindszenty, A., 1994. Well preserved late Precambrian paleosols from northwest Scotland. Journal of Sedimentary Research A64, 264-281.

Robb, L.J., Armstrong , R.A., Waters, D.J., 1999. The history of granulite-facies metamorphism and crustal growth from single zircon U-Pb geochronology: Namaqualand, South Africa. Journal of Petrology 40, 1747-1770.

Roberts, D.H., Long, A.J., 2005. Streamlined bedrock terrain and fast ice flow, Jakobshavns Isbrae, West Greenland; implications for ice stream and ice sheet dynamics. Boreas 34, 25-42.

Roy, M., Clark, P.U., Barendregt, R.W., Glasmann, J.R., Enkin, R.J., 2004b. Glacial stratigraphy and paleomagnetism of late Cenozoic deposits of the north-central United States. Geological Society of America Bulletin 116, 30-41.

Roy, M., Clark, P.U., Raisbeck, G., Yiou, F., 2004a. Geochemical constraints on the regolith hypothesis for the middle Pleistocene transition. Earth and Planetary Science Letters 227, 281-296.

Rudberg, S., 1973. Glacial erosion forms of medium size; a discussion based on four Swedish case studies Zeitschrift fuer Geomorphologie 17, 33-48.

Russel, M., Allison, I., 1985. Agalmatolite and the maturity of sandstones of the Appin and Argyll groups and Eriboll Sandstone. Scottish Journal of Geology 21, 113-122.

Rust, D.J., Summerfield, M.A., 1990. Isopach and borehole data as indicators of rifted margin evolution in southwestern Africa. Marine and Petroleum Geology 7, 277-287. 
Schoof, C., 2005. The effect of cavitation on glacier sliding. Proceedings of the Royal Society A: Mathematical, Physical and Engineering Science 461, 609-627.

Setterholm, D.R., Morey, G.B., 1995. An extensive pre-Cretaceous weathering profile in east-central and southwestern Minnesota. US Geological Survey Bulletin 1989, Chapter H.

Shackleton, N.J., Backman, J., Zimmerman, H., Kent, D.V., Hall, M.A., Roberts, D.G., Schnitker, D., Baldauf, J.G., Desprairies, A., Homrighausen, R., Huddlestun, P., Keene, J.B., Kaltenback, A.J., Krumsiek, K.A.O., Morton, A.C., Murray, J.W., Westberg-Smith, J., 1984. Oxygen isotope calibration of the onset of ice-rafting and history of glaciation in the North Atlantic region. Nature 307, 620-623.

Shaw, R., 1997. Variations in sub-tropical deep weathering profiles over the Kowloon Granite, Hong Kong. Journal of the Geological Society 154, 1077-1085.

Siesser, W.G., 1980. Late Miocene origin of the Benguela upswelling system off northern Namibia. Science 208, 283285.

Stein, A.M., 1992. Basin development and petroleum potential in The Minches and Sea of the Hebrides Basins. Geological Society. London, Special Publications 62, 17-20.

Stewart, A.D., 2002. The later Proterozoic Torridonian rocks of Scotland: their sedimentology, geochemistry and origin, Geological Society Memoir. Geological Society of London. 24

Stoker, M., Bradwell, T., 2005. The Minch paleo-ice stream, NW sector of the British - Irish Ice Sheet. Journal of the Geological Society of London 163, 425-428.

Stoker, M., Bradwell, T., 2011. Quaternary geology of the Summer Isles region - a brief explanation of the Summer Isles Special Sheet, Sheet Explanation of the British Geological Survey. British Geological Survey, Keyworth, Nottingham.

Stoker, M.S., Bradwell, T., Howe, J.A., Wilkinson, I.P., McIntyre, K., 2009. Lateglacial ice-cap dynamics in NW Scotland: evidence from the fjords of the Summer Isles region Quaternary Science Reviews 28, 3161-3184.

Stoker, M.S., Hitchen, K., Graham, C.C., 1993. The geology of the Hebrides and West Shetland shelves, and adjacent deepwater areas, United Kingdom offshore regional report. HMSO for the British Geological Survey, London.

Stokes, C. R., Clark, C. D., 2003. Laurentide ice streaming on the Canadian Shield: A conflict with the soft-bedded ice stream paradigm? Geology 31, 347-350.

Stroeven, A.P., Fabel, D., Hättestrand, C., Harbor, J., 2002. A relict landscape in the centre of Fennoscandian glaciation: cosmogenic radionuclide evidence of tors preserved through multiple glacial cycles. Geomorphology 44, 145-154.

Sugden, D.E., 1976. A case against deep erosion of shields by ice sheets. Geology 4, 580-582.

Sugden, D.E., 1978. Glacial erosion by the Laurentide ice sheet. Journal of Glaciology 20 367-391.

Sugden, D.E., John, B.S., 1976. Glaciers and landscape: a geomorphological approach. Arnold, London.

Sugden, D.E., Watts, S.H., 1977. Tors, felsenmeer, and glaciation in northern Cumberland Peninsula, Baffin Island.

Canadian Journal of Earth Sciences 14, 2817-2823.

Summerfield, M.A., 1991. Global Geomorphology, An introduction to the study of landforms. Longman, London.

Thomas, M.F., 1965. Some aspects of the geomorphology of domes and tors in Nigeria. Zeitschrift für Geomorphologie, Neue Folge 9, 63-81.

Thomas, M.F., 1966. Some geomorphological implications of deep weathering patterns in crystalline rocks in Nigeria. Transactions of the Institute of British Geographers 40, 173-193.

Tingey, R., 1991. The Geology of Antarctica. Oxford University Press, Oxford.

Trewin, N.H., 2002. The Geology of Scotland. The Geological Society, London. 
Twidale, C.R., 1982. Granite landforms. Elsevier, Amsterdam.

Twidale, C.R., 2002. The two-stage concept of landform and landscape development involving etching: origin, development and implications of an idea. Earth-Science Reviews 57, 37-74.

Van Zinderen Bakker, E.M., JH Mercer, J.H., 1986. Major late Cainozoic climatic events and palaeoenvironmental changes in Africa viewed in a world wide context. Palaeogeography, Palaeoclimatology, Palaeoecology 56, 217235.

Ward, J.D., Seely, M.K., Lancaster, N., 1983. On the antiquity of the Namib. South African Journal of Science 79, 175183.

Watts, S.H., 1983. Weathering processes and products under arid arctic conditions. Geografiska Annaler 65A, 85-98.

Weertman, J., 1957. On the sliding of glaciers. Journal of Glaciology 3, 33-38.

Wheeler, J.O., Hoffman, P.F., Card, K.D., Davidson, A., Sanford, B.V., Okulitch, A.V., Roest, W.R., 1996. Geological map of Canada, Map 1860A. Geological Survey of Canada.

White, W.A., 1972. Deep erosion by continental ice sheets. Geological Society of America Bulletin 83, 1037-1056.

Woodcock, N., Strachan, R.A., 2002. Geological History of Britain and Ireland. Blackwell Science, Oxford.

Zumberge, J.H., 1954. Glacial erosion in tilted rock layers. Journal of Geology 63, 149-158. 